\title{
FATORES GENÉTICOS E AMBIENTAIS QUE AFETAM A PRODUÇÃO DE LEITE E DURAÇÃO DA LACTAÇÃO DE UM REBANHO COM DIFERENTES GRUPOS GENÉTICOS HOLANDÊS : GUZERÁ
}

\author{
ALEXANDRE VAZ PIRES \\ Médico Veterinário
}

Orientador: IRINEU UMBERTO PACKER

Dissertação apresentada à Escola Superior de Agricultura "Luiz de Queiroz", da Universidade de São Paulo, para obtenção do título de Mestre em Agronomia. Area de concentração: Nutrição Animal $\theta$ Pastagens.

PIRACICABA

Estado de São Paulo - Brasil

Novembro - 1984 
A

meus pais Pasqualina

e Roldão (em memória),

MINHA GRATIDÃO.

A

Arnaldo Lima, OF EREÇO .

$\bar{\AA}$

Ivanete, DEDICO . 
AGRADECIMENTOS

Ao Prof.Dr. Irineu Umberto Packer pela orientação e amizade de monstradas durante o desenvolvimento deste trabalho.

Ao Prof.Dr. Vidal Pedroso de Faria pelos ensinamentos transmiti dos e por tudo que tem feito pela minha carreira universitária.

A Méd. Veterināria Ivanete Susin pelo auxílio e dedicação na elaboração deste trabalho.

Ao Prof.Dr. Moacir Corsi pelo apoio e incentivo recebidos.

Ao Prof.Dr. Raul D. d'Arce pela colaboração e ensinamentos trans mitidos.

Ao Prof.Dr. Cláudio Maluf Haddad pelas sugestões que muito me foram üteis.

A Fazenda Pinhalzinho pelo fornecimento dos dados tornando pos sivel a realização deste trabalho.

Ao Conselho Nacional de Desenvolvimento Cientifico e Tecnológi co (CNPq) pela ajuda financeira concedida durante a realização do curso.

A Srá. Dulce M.C.D.Lima pela valiosa revisão gramatical.

A todos aqueles que direta ou indiretamente prestaram a sua co boração tornando possivel a elaboração deste trabalho. 
I N D I CE

Página

RESUMO $\ldots \ldots \ldots \ldots \ldots \ldots \ldots \ldots \ldots \ldots \ldots \ldots \ldots \ldots \ldots \ldots \ldots \ldots$

SUMMARY $\ldots \ldots \ldots \ldots \ldots \ldots \ldots \ldots \ldots \ldots \ldots \ldots \ldots \ldots \ldots \ldots \ldots \ldots \ldots$

1. INTRODU

2. REVISÃo DE LITERATURA $\ldots \ldots \ldots \ldots \ldots \ldots \ldots \ldots \ldots$

2.1. Produção de leite $\ldots \ldots \ldots \ldots \ldots \ldots \ldots \ldots \ldots, 4$

2.2. Período de lactação ................. 24

2.3. Relações entre produção de leite $€$ duração

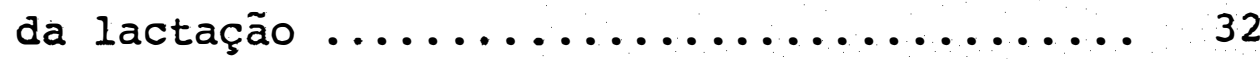

2.4. Herdabilidade da produção de leite e duração da lactação ....................... 34

3. MATERIAL E MEtodos $\ldots \ldots \ldots \ldots \ldots \ldots \ldots \ldots \ldots \ldots . \ldots \ldots$

3.1. Descrição da propriedade ............. 40

3.2. Alimentação e manejo dos animais........ 41

3.3. Descrição dos dados ............... 43

3.4. Análise estatística $\ldots \ldots \ldots \ldots \ldots \ldots \ldots \ldots 44$

3.5. Estimativa da herdabilidade .......... 46

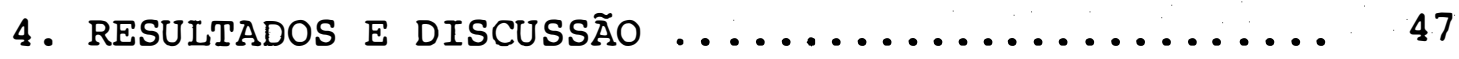

4.1. Produção de leite ................ 47

4.2. Período de lactação $\ldots \ldots \ldots \ldots \ldots \ldots \ldots \ldots .61$ 
Página

4.3. Produção de leite ajustada para duração da lactação ......................... 75

4.4. Estimativas da herdabilidade ......... 81

5. CONCLUSÕES $\ldots \ldots \ldots \ldots \ldots \ldots \ldots \ldots \ldots \ldots \ldots \ldots \ldots \ldots$

6. IITERATURA CITADA $\ldots \ldots \ldots \ldots \ldots \ldots \ldots \ldots \ldots \ldots$

APENDICE $\ldots \ldots \ldots \ldots \ldots \ldots \ldots \ldots \ldots \ldots \ldots \ldots \ldots . \ldots \ldots$ 


\section{LISTA DE TABELAS}

página

Tabela 1 - Estimativas de herdabilidade da produção de leite/lactação na raça Holandesa..........

Tabela 2 - Média de produção de leite $(\mathrm{kg})$ e o número de observações segundo 0 ano de parição...

Tabela 3 - Média de produção de leite e o número de observações segundo a época de parição....

Tabela 4 - Produção de leite estimada em função da idạ de da vaca e fatores de correção multiplica

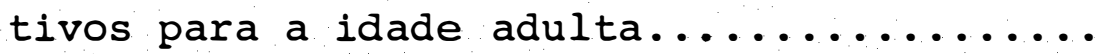

Tabela 5 - Média de produção de leite e o número de obsẹvações segundo o grupo genético......

Tabela 6 - Duração média da lactação, erro da média e o número de observações segundo o ano

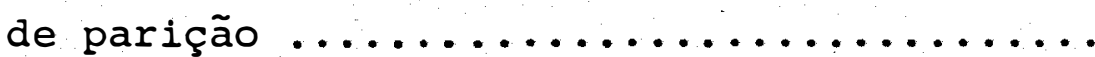

Tabela 7 - Duração média da lactação, erro da média, e númerc de observações por época de parị ção.

Tabela 8 - Duração média da lactação, erro da média, e número de observações de acordo com a

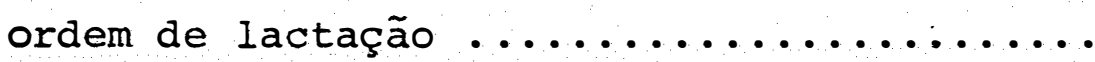

Tabela 9 - Duração média da lactação, erro da média e número de observações segundo o grupo gené-

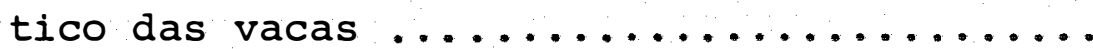


Tabela 10 - Média de produção de leite ajustada para a duração da lactação por covariância e número de observações segundo o grupo ge-

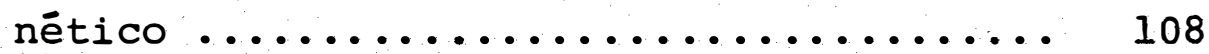

Tabela 11 - Produção de leite estimada em função da duração da lactação e fatores de correção multiplicativos para 305 dias de lactação

Tabela 12 - Análise da variância da produção de leite de acordo com o modelo $3 \ldots \ldots \ldots \ldots \ldots .110$

Tabela 13 - Análise da variância da duração da lactação de acordo com o modelo $3 \ldots \ldots \ldots .$.

Tabela 14 - Análise da variância da produção de leite ajustada para duração da lactação de acor do com o modelo $3 \ldots \ldots \ldots \ldots \ldots \ldots \ldots \ldots$ 


\section{LISTA DE TABELAS (APẼNDICE)}

Păgina

Tabela 1 - Soma mensal de precipitação pluviométrica em $\mathrm{mm}$ no período de 1970 a $1983 \ldots \ldots . .100$

Tabela 2 - Média mensal de temperatura máxima e míni ma em ${ }^{\circ} \mathrm{C}$ no período de 1975 a $1983 \ldots . . .101$

Tabela 3 - Média mensal da umidade relativa do ar em o no período de 1975 a $1983 \ldots \ldots \ldots \ldots . .62$

Tabela 4 - Análise de variância da produção de leite 103

Tabela 5 - Análise de variância da duraçäo da lactação conforme o modelo $1 \ldots \ldots \ldots \ldots \ldots \ldots$

Tabela 6 - Análise de variância da duração da lactação incluindo ordem de parição.........

Tabela 7 - Análise da variância da produção de leite ajustada por covariância para duração da

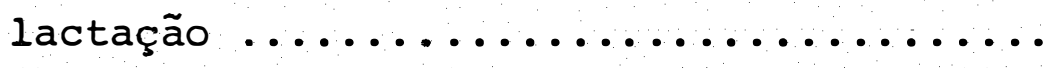

Tabela 8 - Média de produção de leite ajustada para duração de lactação e número de observa ções segundo o ano de parição...........

Tabela 9 - Média de produção de leite ajustada para duração da lactação por covariância e o número de observações, segundo a época de

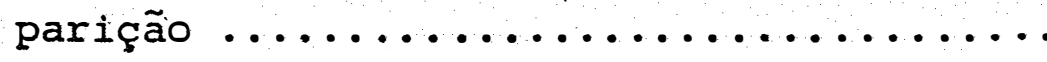




\section{LISTA DE FIGURAS}

Figura 1 - Média de produção de leite segundo o ano de

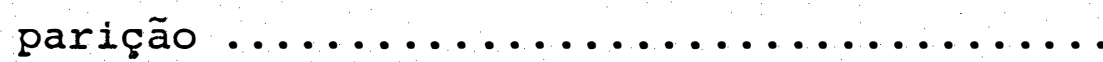

Figura 2 - Efeito da idade da vaca sobre a produção de leite

Figura 3 - Média de produção de leite segundo o grupo

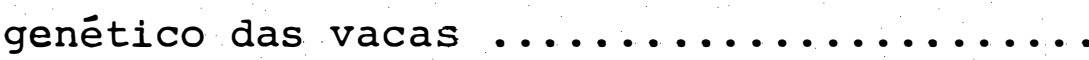

Figura 4 - Duração média da lactação segundo $\circ$ ano

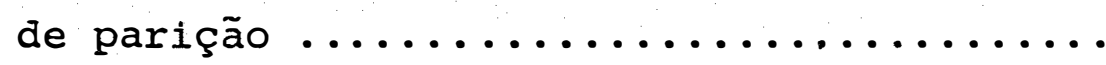

Figura 5 - Efeito da idade da vaca sobre a duração da

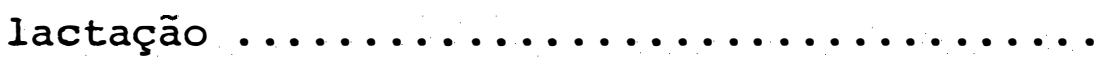

Figura 6 - Duração média da lactação segundo a ordem

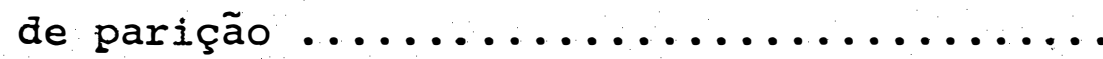

Figura 7 - Duração média da lactação de acordo com o grupo genético das vacas $\ldots \ldots \ldots \ldots \ldots \ldots$

Figura 8 - Curva de resposta da produção de leite em relação à duração da lactação .............

Figura 9 - Média de produção de leite ajustada para du ração da lactação de acordo com o grupo ge-

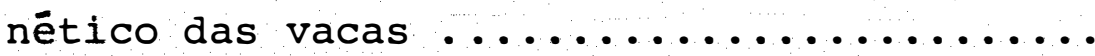

Figura 10- Média de produção de leite ajustada para duração da lactação de acordo com o ano de parição $\ldots \ldots \ldots \ldots \ldots \ldots \ldots \ldots \ldots \ldots$ 
FATORES GENËTICOS E AMBIENTAIS QUE AFETAM A PRODUÇÃO DE LEITE E DURAÇÃO D LACTAÇÃO DE UM REBANHO COM DIFERENTES GRUPOS GENËTICOS HOLANDÉS: GUZERA

Autor: ALEXANDRE VAZ.PIRES

Orientador: IRINEU UMBERTO PACKER

RESUMO

Foram analisados 1.529 registros de produção de leite por lactação e de duração da lactação de 421 vacas pertencentes a seis grupos genéticos $(1 / 2$ Holandês $\mathrm{PB}: 1 / 2$ Guze rá, 3/4 НPB: 1/4GU, 7/8HPB:1/8GU, 15/16HPB:1/16GU e 31/32HPB: $1 / 32 \mathrm{GU})$, no período de 14 anos (1970 a 1983), em quatro épocas de parição correspondentes aos trimestres civis.

A média geral de produção de leite e o respectivo desvio padrão foi $3.007,47 \pm 1.247,61 \mathrm{~kg}$, com um coeficien te de variação de $41,48 \%$. O ano de parição apresentou efeitos : linear e cúbico significativos $(P<0,01)$ sobre a produção de leite, aumentando com o decorrer dos anos. Não houve efeito significativo da época de parição. A idade das vacas na pari ção apresentou efeitos linear e quadrático significativos $(P<0,01)$ sobre a produção de leite. A produção mãxima ocorreu na faixa dos 72 aos 90 meses de idade. O grupo genético de 
terminou aumento linear significativo $(P<0,01)$ na produção de leite com a maior contribuição de genes da raça Holandesa.

A média geral e o desvio padrão da duração da lactação foram $273,72 \pm 69,93$ dias, com um coeficiente de variação de $31,46 \%$. O ano de parição apresentou efeito linear negativo significativo $(P<0,01)$ sobre a duração da lactação, enquanto que a época de parição não apresentou efeito significativo. A idade dos animais apresentou efeito linear significativo $(P<0,01)$ sobre a duração da lactação, aumentando com o decorrer da idade. O grupo genético das vacas determinou aumento linear significativo $(P<0,01)$ da duração da lactação com a maior contribuição de genes da raça Holandẹ sa.

Quando se considerou produção de leite por lactação ajustada para a duração da lactação por covariância, houve remoção da variabilidade genética entre os diferentes grupos genéticos, distorcendo as comparações entre os mesmos de tal modo que as vacas 1/2HPB:1/2GU foram superiores aos de mais grupos.

As estimativas da herdabilidade e os respect vos erro padrão para produção de leite, duração da lactação e produção de leite ajustada para duração da lactação, obtidas pelo método da correlação intraclasse entre meias-irmãs pater nas, foram respectivamente $0,184 \pm 0,068,0,178 \pm 0,067$ e $0,084 \pm 0,044$. 


\section{GENETIC AND ENVIRONMENTAL FACTORS AFFECTING MILK PRODUCTION AND LACTATION LENGTH OF A HERD WITH DIFFERENT GENETIC GROUPS (HOLSTEIN:GUZERA)}

Author: ALEXANDRE VAZ PIIRES

Adviser: IRINEU UMBERTO PACKER

SUMMARY

Analyses were made on 1,529 records of milk production and lactation length of 421 cows representing six different genetic groups (1/2 Holstein: $1 / 2$ Guzera, 3/4 Holstein:1/4 Guzera, 7/8 Holstein:1/8 Guzera, 15/16 Holstein:1/16 Guzera and $31 / 32$ Holstein:1/32 Guzera) during the period of 1970 to 1983; each year parturition evaluated on a quarterly basis.

Average milk production was $3,007 \pm 1,247 \mathrm{~kg}$ with a coefficient of variation of $41.84 \%$ Year of parturition showed linear and cubic effects $(P<0.01)$ on milk production which increased with years. There was no significant effect of season of parturition on milk production. Age of cows at parturition showed linear and quadratic effects $(P<0.01)$ on milk production. Maximum production was obtained from 72 to 90 months of age. The genetic groups showed a linear effect 
$(P<0.01)$ on milk production which increased with higher proportion of genes from Holsteins.

Average lactation length was $273 \pm 70$ days with a coefficient of variation of $31.46 \%$. Year of parturition showed a linear negative effect $(P<0.01)$ on lactation length whereas season of parturition did not. The age of cows showed linear effect $(P<0.01)$ on lactation length, which increased with age. The genetic groups had a linear effect $(P<0.01)$ on lactation length with a greater contribution of genes from Holstein.

When milk production per lactation was adjusted for the lactation length by covariance the genetic variability among different genetic groups was removed which promoted a distortion in the comparison among groups, so that the $1 / 2$ Holstein:1/2 Guzera animals showed a higher milk production as compared to the other groups.

The estimates of the heritability for milk production, lactation length and milk production adjusted for lactation length by the method of intra-class between halfpaternal siblings were, respectively: $1.184 \pm 0.068,0.178 \pm$ 0.067 and $0.084 \pm 0.084$. 


\section{INTRODUÇÃO}

Inúmeros diagnósticos da situação da pecuaria leiteira no Brasil são absolutamente claros ao demonstrar a baixa produtividade dos rebanhos, fato este que determina uma disponibilidade do produto muito aquém das atuais necessidades minimas para o consumo. Todos os analis tas desta situação concordam sobre a necessidade premente de aumentar a produtividade dos rebanhos, através de sistemas de produção mais eficientes, atentando-se para os aspeç tos nutricionais, sanitários e de manejo, além da qualidade genética do rebanho leiteiro.

A melhoria do potencial genético do rebanho pode ser baseada em duas estratégias de longo prazo: substituição do material genético atual por raças especialí zadas e melhora paralela do sistema de produção; (b) exploração de animais mestiços, em sistemas de produção com me- 
nor nivel de tecnologia.

o método clássico, para substituir o material genético de origem zebuína por raças especializadas, consiste no cruzamento absorvente ou contínuo, planejado de tal modo que em gerações sucessivas aumente-se gradativạ mente a contribuição da raça melhoracora. Dentre as raças especializadas a mais comumente usada é a Holandesa. o sucesso desse programa no sentido de aumentar a produtividade dos rebanhos leiteiros depende de uma melhora simultânea do sistema de produção, para que os grupos genéticos com maior proporção de genes da raça especializada tenham condições de expressar o seu maior potencial genético.

No Brasil, muitos programas desta natureza fo ram implantados no decorrer do tempo e muitos encontram-se em fase de implantação, particularmente na região Sudeste. Apesar disso, não existem muitas informações sobre a evolução temporal dos vários indicadores zootécnicos da exploração leiteira ao passar de grupos genéticos mestiços europeu-ze buíno para grupos mais especializados. Ainda que a rentabilidade da exploração leiteira seja uma conseqüência de vãrios Indices relacionados com a produção e reprodução, dentre eles destacam-se dois de grande importância: produção de leite por lactação e duração da lactação.

A anālise estatística e genética dos dados de produção coletados em rebanhos em processo de especiali- 
zação permite obter informações sobre os efeitos dos principais fatores identificáveis do ambiente que afetam a produção de leite e duração da lactação, bem como permite comparar o desempenho das vacas de diferentes grupos genéticos nas condições do sìstema de produção adotado.

Tendo em vista esses aspectos da realidade atual, o presente trabalho foi conduzido com a finalidade de analisar os dados de produção de leite por lactação e duração da lactação obtidos no rebanho da Fazenda Pinhalzinho, Araras,S.P., formado a partir de cruzamento absorvente entre as raças Holandesa preta e branca e Guzerá. Os objeti vos específicos da análise foram:

1) avaliar os efeitos do ano de parição, es tação de parição eidade da vaca sobre a produção de leite e duração da lactação;

2) comparar em um sistema de produção com nível de tecnologia relativamente alto, a produção de leite e a duração da lactação de vacas de diferentes grupos genéticos daquelas duas raças, e, através desses, gerar informações para avaliar o programa de especialização do rebanho; e

3) obter estimativas da herdabilidade da produção de leite e duração da lactação. 
2. REVISÃO DE IITERATURA

\subsection{Produção de leite}

A produção de leite é uma caracteristica de terminada pela ação conjunta do genótipo da vaca e do ambiente ao çaal a mesma está submetida ao longo de sua vida. Do ponto de vista de avaliação dos animais, a produção de leite pode ser considerada em termos de produção em $\mathrm{kg}$ por dia e produção por lactação. Esta última envolve dois componen tes: produção por dia e número de dias em lactação (período de lactação).

As diferenças observadas na produção de leite por lactação em um dado conjunto de registro podem ser devidas aos efeitos dos fatores genéticos e do ambiente.

Dentre os fatores identificáveis do ambiente que determinam variações na produção de leite por lactação 
destacam-se o ano da parição, época ou estação do parto, idade da vaca, ordem da lactação e duração da lactação.

Os fatores genéticos mais comumente considera dos são a composição genética do rebanho, geralmente expressa em termos de graus de sangue ou grupos genéticos, e, o efeito dos touros. Este último é importante para estimar a variação genética aditiva existente no rebanho, demonstrada normalmente em termos da herdabilidade.

\section{Ano de Parição}

A produção de leite pode variar no decorrer dos anos, devido fundamentalmente a duas causas: 1) mudan ças de ordem ambiental envolvendo as modificações qualitati vas e quantitativas da alimentação, tais como: variações clí māticas, particularmente, temperatura e pluviosidade; mudanças no sistema de manejo e sanidade do rebanho, e na orienta ção técnica; 2) mudanças de ordem genética, as quais podem ser atribuídas tanto aos efeitos da seleção das vacas e dos touros, como do sistema de acasalamento usado no rebanho.

Vários estudos conduzidos principalmente em regiões temperadas não mostraram efeito significativo do ano. Assim, SPENCHNT e MCGILLIARD (1960), nos Estados Unidos, analisando lactações de 34.073 vacas holandesas, observaram efeito não significativo do ano sobre a produção de leite. MILLER e HOOVEN (1969) também não notaram efei- 
to significativo do ano de parição sobre a produção parcial e total de leite de vacas holandesas.

HOOVEN et alii (1968), analisando 661 lactações de vacas holandesas não verificaram diferenças signi ficativas entre anos quando compararam apenas a primeira lactação. Entretanto, houve efeito significativo quando ana lisaram todas as lactações. GACULA et alii (1968) observaram efeito significativo do ano de parição sobre a produção de leite, ao estudarem 4.253 lactações de vacas das cinco raças leiteiras mais comuns nos Estados Unidos, encontrando produção média de $5.955 \mathrm{~kg}$ por lactação em 1960 e $6.452 \mathrm{~kg}$ em 1964. Este aumento, segundo os pesquisadores, ocorreu dẹ vido ao uso constante de touros geneticamente superiores, assim como da seleção das melhores vacas, as quais permaneceram nos rebanhos.

No Canadá, LEE (1974) analisou os registros de 59.778 primeiras lactações de vacas holandesas, tendo observado variações significativas de ano para ano (de 1963 a 1967). Houve um aumento na produção de leite no período de 1963 a 1966 e uma diminuição em 1967, não explicada pelo autor.

MCDOWELL et alii (1975, 1976a), estudando 17.255 registros de lactações provenientes de 48 rebanhos do México, encontraram um aumento significativo na produção de leite durante o período compreendido entre anos de 1969 
e 1973. A produção média em 1969 era $4.271 \mathrm{~kg} /$ lactação pas sando para $4.750 \mathrm{~kg}$ em 1973. O aumento foi atribuído ao descarte das vacas de menor produção ao longo desses anos. Ao contrário, CAMOENS et alii (1976). mostraram através da anā lise de 33.950 lactações coletadas em 62 rebanhos de Porto Rico, uma queda na produção de leite, a qual passou de $5.762 \mathrm{~kg} /$ lactação em 1967 para $3.850 \mathrm{~kg}$ em 1972. Tal fato foi atribuído à expansão do número e tamanho dos rebanhos controlados.

Vários trabalhos publicados no Brasil constataram efeito significativo do ano de parição sobre a produção de leite, tanto em rebanhos especializados, como naqueles constituídos de vacas de diferentes grupos genéticos, provenientes dos cruzamentos entre Bos taurus taurus $\mathrm{x}$ Bos taurus indicus.

SABUGOSA e MIRANDA (1963) verificaram efeito significativo do ano de parto sobre a produção de leite por lactação de vacas mestiças (Europeu x Zebu), cuja média de $1.086,6 \mathrm{~kg}$ em 88 lactações, no ano de 1955 aumentou para $2.102,6 \mathrm{~kg}$ em 1962, em 80 lactações não corrigidas para duração da lactação.

ALVES NETO et alii (19.67) analisando 21.144 lactações de vacas da raça holandesa preta e branca, contro ladas pela Associação Paulista de Criadores de Bovinos, encontraram uma produção média de leite de $3.605 \pm 8,5 \mathrm{~kg}$ e 
observaram diferenças significativas entre anos, havendo. contínua ascensão da produção de leite de 1945 a 1958, seguidà de um declínio até 1965 e de um novo aumento em 1966. Segundo os autores a interrupção da curva ascencional foi devida principalmente a fatores econômicos, como a orienta ção adotada pelo poder público em relação ao preço do leite.

Analisando os registros de produção de vacas de diferentes grupos genéticos Holandês x Zebu, NEIVA et alii (1979) obtiveram em 2.000 lactações, não corrigi das para duração da lactação, uma produção média de $3003,52 \stackrel{+}{-} 1010 \mathrm{~kg}$, constatando um decréscimo na produção de leite com o decorrer dos anos (de 1947 a 1975) . Segundo os autores no início do programa houve menor intensidade de seleção uma vez que ocorreu aumento do número de animais no rebanho. Também foi observado uma diminuiç̃̃o do pe ríodo de lactação das vacas além da necessidade de transfe rência de animais para novas áreas ocasionando variações qualitativas e quantitativas na alimentação, bem como mudanças de manejo.

CostA (1980), em Minas Gerais, analisando os registros de produção de um rebanho de vacas da raça holandesa preta e branca, puras por cruza (PC) e puras de origem (PO), também observou efeito significativo do ano de parição no período estudado (1970 a 1979). Houve aumen- 
to da produção até 1975, seguido de decréscimo até 1978, voltando a aumentar em 1979. Segundo o autor, o aumento de produção nos primeiros anos, foi em parte, resultante da seleção realizada a partir de 1965, quando foi formado o rebanho, associado a melhorias de manejo. O decréscimo de produção nos anos seguintes foi atribuido à substituí çãc das vacas mais velhas, por vacas de primeira cria, assim como houve alterações marcantes no manejo, como a instalação do sistema de ordenha mecânica. O aumento de produ ção observado a partir de 1979, foi devido à melhor adaptạ ção dos animais ao sistema de ordenha implantado.

FREITAS (1981) estudou 2.987 lactações de 864 vacas holandesas do rebanho da fazenda São Francico de Bela Vista, localizada na região do vale do Paraíba, Estado de São Paulo, compreendendo o período de 1962 a 1978. o autor observou efeito significativo do ano de inicio da lactação evidenciado pelo aumento da produção de leite com o decorrer dos anos até 1970. Nos dois anos seguintes, 1971 e 1972, houve uma queda acentuada, voltando a aumentar posteriormente. Segundo o autor a diminuição nos anos de 1971 e 1972, ocorreu devido a fatores totalmente adversos ligados a deficiências nas pastagens e sua subseqüente reforma, juntamente com o desiquilibrio nutricional e geadas.

RIBAS (1981) analisou 4.490 registros de produção, fornecidos pelo Serviço de Controle Leiteiro da Associação Paranaense de Criadores de Bovinos, referentes 
a vacas da raça Holandesa preta e branca, puras de origem, pura por cruza e com $31 / 32$ de sangue Holandês, provenien tes de 29 rebanhos associados a Sociedade Cooperativa Cas trolanda Ltda., Município de Castro, Estado do Paraná. Observou efeito significativo do ano do parto sobre a produ ção de leite, no período considerado (1973 a 1978). A prodụ ção média por lactação aumentou de $4.756 \mathrm{~kg}$ em 1973 para $5.339 \mathrm{~kg}$ em 1976, decrescendo para 5.247 e $5.217 \mathrm{~kg}$ nos anos de 1977 e 1978, respectivamente. O aumento inicial foi reflexo da seleção para maior produção, associada à melhora do ambiente. Além disso, ocorreu um aumento no perío do de lactação entre os anos 1973 a 1976. A redução posterior foi atribuída à ocorrência de geadas severas e estia - . gens prolongadas que acarretaram menor disponibilidade de alimentos.

FERREIRA (1983) utilizou os dados de prodụ Ção da Fazenda Santa Helena, situada no Município de Pindamonhangaba, no Vale do Paraíba, Estado de são Paulo, relati vos a vacas holandesas preta e branca, puras de origem ou puros por cruza, com lactaçöes iniciadas de 1964 a 1977 . Oֵ servou efeito significativo do ano de parto sobre a produ ção de leite, a qual aumentou de $2.883 \mathrm{~kg}$ em 1966 para 3.967 kg em 1976, seguido de um decréscimo em 1977. o aumento pode ter sido causado pela seleção das vacas de maior produção e pela melhoria progressiva de manejo e alimentação desses animais. 
NOBRE (1983) utilizou 997 registros de produção de leite fornecidos pelo Departamento de Zootecnia da Universidade Federal de Viçosa, Estado de Minas Gerais, referentes a vacas puras por cruza e mestiças da raça Holande sa preta e branca. O ano de parto influiu significativamente sobre a produção de leite, no período estudado (1969 a 1981). O decréscimo da produção nos anos iniciais (1969 a 1973) refletiu alterações marcantes de ambiente, manejo e, principalmente, alimentação suplementar. O aumento observado a partir de 1977 foi atribuido principalmente à constân cia no fornecimento de alimentação suplementar às vacas em lactação, além de melhores condições de manejo, profilaxia e a seleção visando o aumento da produção de leite.

\section{Epoca de Parição}

As diferenças climáticas entre as vārias épo cas do ano támbém podem alterar a performance dos animais. A produção de ileite é influenciada direta e indiretamente pela temperatura, luminosidade e precipitação pluviométrica. o efeito direto do clima, particularmente, das altas temperaturas do verão, as quais afetam o conforto e a eficiência do animal se resume, em geral, na diminuição do consumo de alimentos e conseqüente queda na produção de leite. De mo do indireto, as condições climáticas exercem pronunciado efeito sobre a quantidade e qualidade das plantas forrageiras (MCDOWELL, 1972). Conseqüentemente, o efeito da época 
de parto sobre a produção de leite depende em larga escala do nível de tecnologia da exploração, ou seja, esse efeito será tanto mais evidente quanto maior for a dependência de pastagens. Por outro lado, essé efeito é reduzido quando o suprimento de alimentos de alta qualidade ocor re durante todo o ano.

- Nos Estados Unidos, diversos autores observaram que a produção de leite das lactações iniciadas no inverno são maiores do que aquelas iniciadas no verão (BRoWN et alii, 1960; VAN VLECK e HENDERSON, 1961; SARGENT et alii, 1967; MILLER et alii, 1970; BRANTON e EVANS, 1972; RIOS e BRANTON, 1973; HARDIE et alii, 1978).

HICHMAN e HENDERSON (1955) estudando a produção de leite de 1904 rebanhos constituídos de vacas de raça Holandesa, no estado de New York, observaram melhores produções quando iniciadas no outono. Já BLANCHARD et alii (1966) verificaram, na mesma. raça e paỉs, que as lactações iniciadas no final do outono e no inverno. tiveram um aumento de 5\% na produção de leite quando comparadas com aquelas iniciadas no final da primavera e verão. Por outro la do, BRANTON et atii(1974), nas condições de Lousiania, verifica ram que a produção de leite das vacas holandesas, que pariram na estação quente do ano, foi 200 a $300 \mathrm{~kg}$ (5-8\%) menor do que aquelas que iniciaram a lactação na estação fria. 
No Chile, GOIC (1974) determinou a curva de lactação de vacas holandesas em relação à época da pari ção tendo observado que o outono e o inverno foram as melhores épocas. para produção de leite.

Em Porto Rico, CAMOENS et alii (1976) veri ficaram que as menores produções eram resultantes das lactações iniciadas na época chuvosa e quente. Ao contrārio, no México, em condições de clima subtropical, McDOWELL et alii (1976a) observaram que as vacas com lactações iniciadas nos meses de julho a agosto (verão) produziram $299 \mathrm{~kg}$ acima da média de produção de leite do rebanho.

MCDOWELL et alii (1976b), nos Estados Unidos, notaram que as vacas holandesas de $1^{a}$. lactação que pạ riram em janeiro e fevereiro produziram 7\% mais leite e apresentaram 32 dias a menos de período de serviço, do que as vacas que pariram em julho e agosto. Os autores relataram que as condições climāticas exercem grande influência nos primeiros 60 dias de lactação. Durante este período, temperaturas acima de $27^{\circ} \mathrm{C}$ a $28^{\circ} \mathrm{C}$ causaram diminuição do consumo de alimento e conseqüentemente rápida utilização das reservas corporais e grandes perdas de peso corporal. Inversamente, as temperaturas baixas estimularam o consumo de alimento resultando em maiores produções.

De acordo com ALVES NETO (1967), no Brasil, em 21.144 lactações de vacas da raça Holandesa preta e 
branca, controladas pela Associação Paulista de Criadores de Bovinos, no período de 1945 e 1966, a produção de leite das lactações iniciadas nos meses de maio a agosto foram maiores do que aquelas dos meses de novembro a fevereiro.

COSTA et alii (1976) analisando as lactạ ções de vacas das raças Holandesa, Jersey e Ayrshire veri ficaram que o inverno e a primavera foram as melhores estações para início da lactação.

REIS (1977) notou que as melhores médias de produção de leite foram aquelas dos meses de julho a agosto (inverno), observação esta realizada em um rebanho mestiço (Europeu x Zebu). SIQUEIRA (1979), em um estudo com 1.026 lactações, num período de 13 anos constatou que as maiores produções pertencem a vacas paridas no outono, seguidas do inverno, primavera e verão.

NEIVA (1979) trabalhando em Minas Gerais, com vacas de diferentes graus de sangue holandês observou que as lactações iniciadas no outono e inverno alcançaram as mais altas produções. A diferença de produção entre as estações foi $79,18 \mathrm{~kg}$.

$$
\text { COSTA (1980) e NOBRE (1983) verificaram }
$$

maior produção nas lactações iniciadas na estação seca e fria comparativamente aquelas iniciadas na estação chuvosa e quente. Segundo estes autores tal fato é um reflexo direto 
das condições climāticas mais compatíveis com as exigidas pela raça Holandesa,como também reflete uma melhor qualidade e quantidade dos alimentos, uma vez que naquela época a alimentação dos animais era baseada na silagem de milho e ou sorgo.

Segundo FREITAS (1981), na região do Vale do Paraíba, Estado de são Paulo, as maiores produções (ce r ca de $4.500 \mathrm{~kg}$ ) de vacas holandesas ocorriam nas lactações iniciadas nos meses de maio e junho, correspondente a estação da seca e com temperaturas mais amenas. Por outro la do, as menores produções (aproximadamente $4.000 \mathrm{~kg}$ ) foram provenientes das lactações iniciadas em janeiro e fevere ro.

Ainda no Brasil, diversos autores constataram que as lactações de vacas da raça Holandesa iniciadas na estação seca e fria apresentam maior produção de leite (RIVEROS, 1979; MANDUJANO, 1979; RIBAS, 1981; FERREIRA, 1983).

Por outro lado, outros autores brasileiros não encontraram efeito significativo da época de parição sobre a produção de leite (OLIVEIRA, 1973; DIAS et alii, 1974; LOBO, 1980 e PRIMO et a $2 i i$, 1980).

Idade da Vaca

A produção de leite varia com a idade da 
vaca, aumentando a partir da primeira lactação até atingir o desempenho máximo, o qual coincide com a plena maturidade fisiológica, decrescendo a seguir. Essa variação è consequência das alterações anátomo-fisiológicas no organismo, particularmente no úbere, decorrentes do aumento da idade do animal. As vacas adultas podem produzir cerca de 25\% a mais de leite comparativamente às vacas de primeira cria. O aumento do peso corporal responde por aproximadamente 5\% desse acréscimo, enquanto que os outros $20 \%$ são resultado do desenvolvimento do úbere nas gestações seguintes (TUCKER, 1979).

Segundo LUSH e SHRODE (1950), para a maioria das raças leiteiras européias, as vacas atingem o máxí mo de produção em torno dos 6 a 8 anos, declinando a seguir. Em alguns casos, o efeito da idade sobre a produção está associado ao peso do animal, principalmente à primeira parição, pois na vaca adulta tanto o sistema digestivo como as glândulas mamárias estão plenamente desenvolvidos.

De acordo com FARTHING e LEGATES (1957) e ERB (1960), o efeito da idade sobre a produção envolve três aspectos: durante a primeira e segunda lactações a produção está diretamente relacionada com a idade à parição; na terceira a produção è independente e nas demais existe relação inversa entre idade e produção. 
produção perdem peso e as de baixa produção ganham peso no decorrer da lactação. Entretanto, deve ser considerado que a capacidade produtiva das vacas sofre influência não apenas da idade e do peso, mas também do desenvolvimento do úbere, o qual não está plenamente desenvolvido antes da terceira ou quarta lactação. Quanto mais cedo ocorrer a primeira parição maior número de lactações terá a vaca e maior será a produção em sua vida útil. No entanto, a produção máxima na primeira'lactação é obtida com novilhas parindo em torno dos 36 a 42 meses de idade.

GACULA et alii (1965) trabalhando com vacas holandesas, nos Estados Unidos, constataram que a idade da vaca foi responsável por 14 a 30\% da variação total na produção de leite, e,que a produção máxima ocorreu na faixa etária dos 5 aos 7 anos, No mesmo país vários outros aụ tores estudaram o efeito da idade sobre a produção de leite de vacas da raça Holandesa, tendo sido verificado um efeito quadrático com produção máxima entre os 70 e 85 meses (BLANCHARD et alii, 1966; SARGENT et alii, 1967; BRANTON et alii, 1974).

De acordo com LOGANATHAN e THOMPSON (1968), também nos Estados Unidos, a idade do primeiro parto foi responsável por 10 a 14,3\% da variação total observadạ na produção de leite em 4.664 lactações.

Vários trabalhos publicados em países de 
clima tropical e sub tropical tais como VERDE et alii (1972), na Venezuela, JARA e WHITE (1972), no Peru, GAMEZ et alii (1972) e MCDOWELL et alii (1976a), no México, verificaram que a ordem ou a idade da vaca ao parto influencia significativamente a produção de leite, com as maiores produções ocorrendo entre 70 e 80 meses de idade.

NAUFEL (1965/66) e SIQUEIRA (1979), estudando o. desenvolvimento de rebanhos da raça Holandesa, em diferen tes regiões do Brasil, relataram que a produção de leite au mentou com a idade alcançando valor máximo entre os 6-8 anos.

COSTA (1980) verificou que a idade das vacas da raça Holandesa exerceu influência de forma quadrática, alcançando uma produção máxima entre os 84 e 90 meses de idade, correspondente a quinta ordem ảe parto.

De acordo com RIBAS (1981), a idade da vaca ao parto exerceu influência quadrática significativa sobre a produção de leite, tendo sido uma das mais importan tes fontes de variação, responsável por 13,1\% da soma de quadrado total. A produção máxima por lactação foi obtida aos 85 meses de idade, correspondente à quinta ordem de parição. Nesse rebanho a idade média no primeiro parto foi 33,2 meses.

Segundo FREITAS (1981) no Vale do Rio Paraí- 
ba, Estado de São Paulo, a produção máxima de leite, entre 4.500 a $5.000 \mathrm{~kg}$ em um rebanho de vacas holandesas, foi atingida com 66 a 78 meses de idade.

Trabalhando com vacas de diferentes grupos genēticos Holandês $x$ Zebu, NOBRE (1983) verificou efeito quadrático da idade da vaca ao parto sobre a produção de leite. A idade da vaca foi uma das mais importantes fon tes de variação, respondendo por cerca de 6,3\% da soma de quadrado total. A produção máxima por lactação foi observada aos 132 meses de idade, correspondendo à sétima ordem de parição. O autor atribuiu esse fato à elevada idạ de ao primeiro parto, 39,3 meses, associada a intervalo entre partos de aproximadamente 13 meses. Além desse aspec to a idade média geral dos animais era 74 meses, indicando que vacas mais produtivas foram mantidas por mais tempo no rebanho.

De acordo com FERREIRA. (1983), a idade da vaca ao parto exerceu feito quadrático sobre a produção de leite, de tal modo que a produção máxima ocorreu entre 108 e 120 meses, correspondendo da quinta à sétima lactação.

\section{Grupo Genetico}

Um dos métodos mais comuns para melhorar o potencial genético de produção de leite dos rebanhos não especializados consiste no cruzamento absorvente, ou seja, 
através do uso contínuo de reprodutores da raça melhorado ra, aumenta-se em gerações sucessivas a contribuição dessa raça especializada (SCHMIDT e VAN VLECK, 1974). Tendo em vista que a exteriorização desse maior potencial genétí co das vacas necessita de ambiente mais adequado, torna se evidente que o sucesso do programa de cruzamento absorvente depende de uma melhora gradativa da tecnologia de produção.

Inúmeros programas de cruzamentos absorventes em gado leiteiro foram implantados nas regiões tropicais e semitropicais (KATPATAL, 1982). O Brasil não constị tui exceção. Através desse esquema procura-se melhorar a produção de leite de vacas zebuinas; em particular das raças Gir e Guzerá. De modo geral, a raça leiteira mais empregada nos cruzamentos é a Holandesa preta e branca (HPB) e vermelho e branco (HVB) (PEREIRA, 1983).

Vārios pesquisadores têm procurado estudar os efeitos dos diferentes grupos genéticos provenientes dos cruzamentos entre raças leiteiras européias com raças zebuinas sobre a produção de leite. Os resultados relata dos na literatura evidenciam o efeito desses diferentes grupos genéticos. No entanto, a magnitude observada desse efeito depende em larga escala do nível tecnológico empregado na produção de leite bem como da diversidade entre os grupos genēticos sob comparação (MADALENA et alii, 1982).. 
PEIXOTO (1965), ao analisar 151 lactações de vacas azebuadas e mestiças ( $1 / 2,3 / 4$ Guernsey) do rebanho do Departamento de Zootecnia da ESALQ/USP, encontrou diferença altamente significativa entre esses grupos genéticos quanto à produção de leite corrigida para 305 dias de lactação. As produções observadas foram 479,44; 1995,58 e 1794,04 kg de leite/lactação para as vacas azebuadas, 1/2 3/4 Guernsey, respectivamente.

ALVES NETO (1967), analisando 15.101 lactạ ções de vacas holandesas preta e branca, entre os anos de 1945 a 1963, verificaram melhores produções em 305 dias, para as vacas puras de orịgem $(3.777 \mathrm{~kg})$ em relação às puras por cruza e/ou mestiças $(3.620 \mathrm{~kg})$.

VENCOVSKY et alii (1970) relataram maior produção de leite nas vacas $F_{l}(2.527 \mathrm{~kg})$ e 5/8 HPB: 3/8 Guzerá $(2.567 \mathrm{~kg})$. As demais produções foram 1.582, 1.852, $1.992,2.238,2.435,2.336,2.332 \mathrm{~kg}$ de lẹte para os seguintes grupos genéticos: Zebu (Guzerā); 1/8; 1/4;3/8 Guzerá; 3/4; 7/8 Holandês e Holandês $\mathrm{PB}$, respectivamente.

NEIVA et alii (1979) não observaram efeito do grupo genético sobre a produção de leite ao analisarem 2.000 lactações, cuja média foi de $3.003,52 \mathrm{~kg}$ não ajustadas para duração da lactação provenientes de um rebanho de Minas Gerais, constituído por vacas de diferentes grupos 
genéticos holandès $\mathrm{x}$ zebu $(1 / 2,3 / 4,7 / 8)$ e PC e PO, no período de 1947 a 1975. Segundo os autores esse resultado foi devido ao manejo e alimentação similares para todos os animais, independentemente do grupo genético. Além disso, houve maior descarte entre os animais mestiços, permanecendo no rebanho somente aqueles que se aproximavam das produções desejadas.

\section{RIVEROS (1979) analisando 3.569 lactações}

de duas categorias de vacas holandesas com uma média de $3: 136,99 \mathrm{~kg}$ de leite não encontrou diferença significativa na produção de vacas PC e PO. .

De acordo com LOBO (1980), em 5.270 lactações não corrigidas para duração da lactação de animais da raça Pitangueiras, foi observada produção de leite mais elevada $(2.780 \mathrm{~kg}$ em 281 dias de lactação) e um maior período de lactação para as vacas $5 / 8$ Red Poll e 3/8 Zebu, quando comparadas com os cruzamentos $1 / 2$ Red Poll : 1/2 Zebu e 1/4 Red Poll : 3/4 Guzerá. Por outro lado, as vacas 1/4 Red Poll : 3/4 Guzerá foram inferiores em produção ao 1/2 Red Poll : 1/2 Zebu.

MADALENA et alii (1983) não encontraram diferenças significativas na produção de leite de 55 vacas da raça Holandesa preta e branca (HPB), 35 do grupo 7/8 HPB x 1/8 Gir e 53 vacas 3/4 $\mathrm{HPB}$ x 1/4 Gir, em Minas Gerais. As 
produções foram $4.199 \pm 318 ; 3.894 \pm 263$ e $4.034 \pm 252 \mathrm{~kg} /$ lactação, respectivamente, para os três grupos citados. A ausência do efeito do grupo genético foi atribuída ao alto nível de produção e clima favorável.

Segundo FERREIRA (1983), trabalhando com 390 vacas $\mathrm{HPB}$ ( $\mathrm{PC}$ e $\mathrm{PO}$ ) em Pindamonhangaba, Estado de são Paulo, com um total de 1.389 lactações corrigidas para 305 dias de duração da lactação e com uma idade média de 50,6 meses,foi encontrada una média de produção de leite de $3: 714,5 \mathrm{~kg}$. Apesar de as diferenças não terem sido significativas, as vacas PC tenderam a produzir mais leite $(3.553,09 \mathrm{~kg})$ do que PO $(3.449,54 \mathrm{~kg})$. De acordo com o autor esse resultado pode estar associado a uma seleção mais intensa feita nos animais PC, por serem de menor valor comercial e, também, por jā estarem mais adaptados ao meio ambiente, tornando - se, portanto, tão produtivas quanto os animais PO.

$$
\text { MADALENA et alii (1982) constataram uma }
$$

interação altamente significativa entre grupo genético das vacas e nível de manejo sobre a produção de leite em kg por lactação. Em regime de manejo alto as produções foram de: $3.438 ; 3.076 ; 3.322 ; 1.622 ; 3.235 ; 1.443$; para vacas holandesas; 7/8H; $3 / 4 \mathrm{H} ; 5 / 8 \mathrm{H} ; 1 / 2 \mathrm{H}$ e 1/4 H, respectivamente. Na situação de baixo nível de manejo obtiveram produções de: $772 ; 1.959 ; 1.717 ; 1.474 ; 2.322 ; 859$, respectivamente para os mesmos grupos genéticos. Tais resultados: șugerem 
que o efeito do grupo genético das vacas depende em grande parte do nível de manejo da exploração.

\subsection{Período de lactação}

o período de lactação é definido pelo número de dias que a vaca está em produção de leite. Assim sendo, constitui um componente fundamental da produção total de leite por lactação, a qual será tanto maior quanto maiores forem a produção média de leite por dia e o número de dias de lactação.

A duração do período de lactação está relacionạ da cóm a persistência da produção de leite. A persistência é uma medida da queda da produção no decorrer do período de lactação. Quanto. maior a persistência maior será o período de lac tação. O término da lactação pode ocorrer de modo natural nas vacas de menor persistência ou por motivos externos como, por exemplo, doenças. As vacas com lactação prolongada, porēm com baixa produção de leite, têm a lactação encerrada pelo produtor por razões de ordem econômica.

Para as raças leiteiras especializadas, considera-se como ideal um período de lactação de 305 dias. Desse modo, em um ano, restam 60 dias de período seco. Através desse manejo, cada vaca terá um prazo de até 90 dias para ser fertilizada após o parto. Considerando-se um período de gestação de 275 dias, obtém-se assim um intervalo entre 
partos da ordem de 12 meses, ou seja, uma lactação/ano (TE CKER, 1979).

O período de lactação, componente funda mental da produção de leite por lactação, sofre o efeito de fatores ambientais e genéticos. Entre os ambientais os mais comumente considerados são: ano de parição, época de parição, idade da vaca. Entre os genéticos são considera dos o efeito dos grupos genéticos das vacas bem como o efeito dos reprodutores.

\section{Ano de parição}

Conforme citado anteriormente, o ano de parição pode exercer efeito sobre a duração da lactação. o período médio de lactação de acordo com o ano pode. variar provavelmente pelas mesmas causas mencionadas na produção de leite.

De acordo com McDOWELL et alii (1975), no México, ao analisarem 17.255 lactações provenientes de 48 rebanhos, abrangendo o período de 1969 a.1973, constataram um aumento médio de 19 dias na duração da lactação. Ao contrārio, CAMOENS et alii (1976), em Porto Rico, estudan do 1.900 lactações de vacas holandesas pertencentes a 25 re banhos, verificaram uma duração média da lactação de $296 \pm 15,8$ dias em 1967 e $275 \pm 52,3$ dias em 1972. 
No Brasil, ALVES NETO et alii (1967) observaram que a duração média do período de lactação de vacas da raça Holandesa submetidas ao controle leiteiro oficial, apresentaram diferenças relacionadas com o ano variando de 213,5 dias em 1945, para 284,2 dias em 1966. A média geral em 2l.144 lactações foi 267,4 dias:

MANDUJANO (1979), estudando 1.020 lactações de vacas holdandesas, relatou efeito significativo do ano de parto sobre o período de lactação, observando em 1955 o menor período $(242,8$ dias) e, em 1970; o maior $(307,8$ dias).

De acordo com RIBAS (1981) a duração do período de lactação aumentou a partir de 1973 (306,8 dias), atingindo o máximo entre 1975 e 1976 (cerca de 310 dias), decrescendo em 1977 e 1978 (308,9 a 294,8 dias, respectiva mente). A média geral do período de lactação foi 306,5 I 1,8 dias, com um coeficiente de variação igual a. 15,3․․ Pa ra o autor, tais decréscimos relacionaram-se à ocorrência de severas geadas e estiagens, comprometedoras do fornecimento: de volumosos adequados, aos rebanhos. Além disso, a queda foi atribuída tambēm à tendência dos criadores de não permitirem que a lactação se prolongasse muito além de 305 dias, visando reduzir o intervalo entre partos.

NOBRE (1983) analisando os dados obtidos com 
vacas de diferentes grupos genéticos observou grandes variações na duração do período de lactação ao longo dos anos, cujo valor decresceu a partir de 1970, atingindo um mínimo em 1975 (202,7 dias) para a primeira época de parição referentes aos anos de 1969 a 1975. Já na segunda épooa de parị ção (1976 a 1981) a duração da lactação apresentou novamente um declínio a partir de 1977 até o ano de 1981, no qual o mínimo de 205 dias foi alcançado. A média geral do período de lactação referente a 997 registros foi $245 \pm 8,86$ dias, com um coeficiente de variação de $27 \%$

\section{Estação de parto}

A estação do mês de parição pode influenciar a duração da lactação, provavelmente em virtude dos efeitos diretos e indiretos das condições climáticas peculiares a cada época. Vários autores constataram o efeito da época da parição sobre a duração da lactação.

GOIC (1974), no Chile, observou menor período de lactação de vacas holandesas paridas no verão, como conse qüência direta da qualidade das pastagens. No México, McDoWELL et alii. (1976a), em condições de clima subtropical,..observaram que as lactações mais longas foram aquelas inicia das entre julho a dezembro.

KIWUWA (1974), trabalhando no Quênia com vacas da raça Holandesa e Jersey, encontrou períodos mais curtos 
para as lactações iniciadas na estação quente e chuvosa (março a julho). No entanto CAMOENS et alii (1976), em Porto Rico, observaram que a duração do periodo de lactação não foi afetada pela época de parição.

De acordo com BRANTON et alii (1974), nos Estados Unidos, os períodos de lactação mais curtos de 1.388 vacas da raça Holandesa estavam associados às pạ rições na estação mais quente do ano.

No Brasil, ALVES NETO (1967) observou que as lactações iniciadas nos meses de maio e julho $(269,5$ e 270,8 dias, respectivamentel foram mais longas, decrescendo continuamente até dezembro (259,4 dias). RIBAS (1981) relatou efeito significativo da época de parição sobre a duração da lactação. As lactações mais longas foram iniciadas de dezembro a maio, isto é, no verão e no outono, e as menores aquelas iniciadas entre os meses de junho e agosto.

NOBRE (1983) encontrou resultados conflitan tes, ou seja, as lactações mais longas foram iniciadas em abril e julho, isto é, no outono e inverno ao passo que as menores foram iniciadas nos meses de janeiro e outubro.

\section{Idade da Vaca}

A idade da vaca bem como a ordem de lactação podem influenciar o período de lactação. 
Analisando 40.000 lactações nos Estados Uni dos, SCHAEFFER e HENDERSON (1972) verificaram maior período de lactação para o primeiro parto (321 \pm 40 dias) decrescendo nos partos subsequentes. No mesmo país, BRANTON et alii (1974) observaram em vacas holandesas pertencentes a cinco rebanhos que o período de lactação foi afetado de modo linear pela idade da vaca, ou seja, as vacas com menos de 36 meses de idade apresentaram maior período de lactação, decrescendo com aumento da idade.

CAMOENS et alii (1976), em Porto Rico, e MCDOWELL (1976), no México, não encontraram efeito significativo da idade da vaca na duração do período de lactação.

ALVES NETO et alii (1967) observaram em rebanhos constituídos por vacas da raça Holandesa que o período de lactação foi mais longo para as vacas mais jovens, aumentando até os 7 anos de idade e decrescendo linearmente com o avanço da idade. Segundo os autores, o período mostrou-se mais longo nas primeiras lactações, talvez devido à melhor atenção dos criadores ou porque os animais utiliza ram as reservas de energia acumuladas durante a fase de criação. A partir dos 7 anos as lactações tendem a dimi nuir sua duração: devido ao interesse dos criadores por maior número de crias das vacas testadas ou ao desgaste ou a outras razões-

Em 180 lactações de um rebanho de vacas holan- 
desas preta e branca, VALLE e NALI (1978) verificaram que a duração da segunda lactação foi a maior $(332,38$ dias) e na quinta lactação a menor $(314,5$ dias), sendo a média geral para as cinco lactações estudadas igual a 324,15 dias. Estas oscilações na duração da lactação conforme a ordem de parição, principalmente o decrēscimo da duração e prodụ ção na quinta lactação, seria devido aos longos períodos de ordenha nas primeiras lactações. -

De acordo com RIBAS (1981) a idade da vaca ao parto influenciou significativamente a duração do perío do de laçtação. As vacas mais jovens apresentaram maior período de lactação, o qual declinou linearmente com o avanço da idade.

De acordo com NOBRE (1983), a idade da vaca ao parto influenciou de forma linear significativa a duração da lactação. O efeito da idade da vaca foi responsável por cerca de $0,98 \%$ da soma de quadrado total do perỉodo de lactação. As vacas mais jovens apresentaram maior período de lactaçãc que decrescia com o aumento da idâ de.

\section{Grupo Genético}

Várias pesquisas têm sido realizadas no sen tido de caracterizar o efeito do grupo genētico sobre a duração da lactação. 
BRANDT et alii (1966) e BRANTON et ali (1967), nos Estados Unidos, observaram uma variação muito grande no período de lactação das vacas mestiças (Holandês x Zebu), quando comparadas com as holandesas puras, havendo tendência para aumentar a duração na medida em que se acrescentava a contribuição de genes da raça Holandesa. Entretanto, KASSIR et alii (1969), no Iraque, estudando vacas mestiças e puras de origjem (PO) da raça Holandesa, não encontraram diferenças no período de lactação.

ALVES NETO (1967) estudando a duração da - lactação de vacas puras por cruza e puras de origem da raça Holandesa encontrou diferenças significativas entre esses dois grupos. Em 15.090 períodos de lactação analisados, observou uma superioridade de aproximadamente 10 dias para as vacas puras de origem. Por outro lado, MANDUJANO (1979) não encontrou diferenças significativas no período de lactação de vacas puras por cruza e puras de origem da raça Holandesa.

Trabalhando com dados coletados em fazendas com baixo nível de manejo, MADALENA et alii (1980) encon traram 35, 25 e 13\% de lactações com menos de 120 dias de duração, para as vacas HPB, 3/4 HPB x 1/4 Gir e 1/2 HPB x 1/2 Gir, respectivamente.

Segundo RIBAS (1981) o grupo genético das vacas leiteiras não influenciou o período de lactação. As 
médias dos três grupos genēticos (PO, PC e 31/32 Holandês) foram idênticas, ou seja, 306 dias de lactação.

MADALENA et alii (1982) encontraram médias de duração da primeira lactação nos diferentes grupos genéticos Holandês x Guzerá (HPB, 7/8, 3/4, 5/8, 1/2 e 1/4 Holandês) em várias fazendas com alto nỉvel de manejo, de $404,318,315,203,322$ e 225 dias; 154, 289, 275, 260, 307 e 155 dias para as fazendas com baixo nível de manejo, respectivamente. Esses resultados mostram que a duração da lactação de vacas de diferentes grupos genēticos depende do nível de manejo da exploração. Entretanto, MADALENA et alii (1983) não encontraram diferença no período de lactação de vacas mestiças HPB x Gir, com grupos genéticos 3/4 $\mathrm{HPB}$ e $7 / 8 \mathrm{HPB}$ e as HPB puras. Tais resultados foram -atribuídos ao alto nível de produção bem como ao clima favorável da região.

\subsection{Reläções entre produção de leite e duração da $\underline{\text { lactação }}$}

Trabalhos experimentais têm mostrado que 0 período de lactação constitui uma importante causa de variação na produção de leite por lactação. LOGANATHAM e THOMPSON (1968) destacaram que a duração de lactação contribuiu com 14 a I8\% da variação observada na produção de leite. Já McDOwELL et alii (1975), em 18.630 registros de. 
produção de leite de 55 rebanhos de vacas holandesas, no México, verificaram que a duração da lactação foi respon sāvel por 33,9\% da variação na produção de leite. Enquanto que NEIVA et alii (1979), ao analisarem a influência de vārios fatores não genéticos sobre 2.000 registros de produção de leite no Brasil, relataram que a duração da lactação foi responsável por $41,5 \%$ da lactação.'

FREITAS (1981) encontrou efeito linear da duração da lactação sobre a produção de leite. Observou uma correlação positiva entre número de dias de lactação e produção total de leite na lactação. Segundo o autor, dentro de certos limites, quanto mais tempo a vaca produz maior será a sua habilidade produtivà e sua persistência, pois as vacas de menor produção atingem rapidamente seu pico de lactação diminuindo a seguir o seu desempenho.

A necessidade de corrigir as produções de vacas quando se tem apenas parte das lactações ou períodos inferiores a 305 dias, cujas causas do registro incompleto sejam apenas ambientais não sendo relacionadas à habilidade genética das vacas em completar um período de lactação normal, estā bem justificada pela literatura (JOHANSSON, 1961; JOHANSSON e RENDEL, 1972; WEBB, 1977; WARWICK e LEGATES, 1979); assim como as formas de obterse os fatores de correção para estender parte das lacta ções a um período padrão, geralmente 305 dias (VAN VLECK 
e HENDERSON, 1961; WIGGANS e VAN VLECK, 1979).

Incluindo-se todas as lactações obtidas no período estudado ou excluindo-se aquelas de período muito longo ou muito curto, quando comparado aos 305 dias, obtem-se resultados diferentes, muitas vezes, não traduzindo a realidade do rebanho. O mesmo acontece quando se aplicam fatores de correção. BRANTON et alii (1967) incluíram nas anālises todas as lactações, independentemente da duração, a menos que fossem terminadas por doença ou acidente.

\subsection{Herdabilidade da produção de leite e duração da} lactação

O conhecimento da herdabilidade $\left(\mathrm{h}^{2}\right)$ de um determinado caráter é um dos elementos básicos a considerar quando se deseja estimar o progresso que pode ser ob tido pela seleção (LUSH, 1949).

No melhoramento animal, a finalidade primor dial da seleção é, sem dúvida, o aprimoramento da geração futura. Quando os animais são escolhidos para a re produção, espera-se que parte da sua superioridade média seja transmitida à progênie. Sendo a seleção baseada no fe nótipo dos animais, é necessārio saber a proporção das diferenças fenotípicas atribuída aos efeitos médios dos genes. A estatística que representa essa proporção é defini- 
da como herdabilidade. Considerando o seu valor e a inten sidade de seleção praticada na população pode-se obter a taxa de progresso genético ao longo das gerações (LUSH, 1949).

A herdabilidade de uma característica mede - grau de correspondência entre o valor fenotípico e o valor genético aditivo. Embora o valor genético do indivíduo determine a sua influência na próxima geração, somente o valor fenotípico pode ser medido diretamente. Assim, o sucesso do criador na escolha de individuos, mediante seus fenótipos,depende, principalmente, dos valores da herdabilí dade das características (FERREIRA, 1983).

De modo geral, os diferentes resultados encontrados na literatura são decorrentes de numerosos fatores em particular, população e do método de estimação. As estimativas de herdabilidade são, usualmente, feitas den-.. tro do rebanho procurando eliminar ao máximo as variações sistemáticas do ambiente, obtendo, assim, resultados mais precisos. E importante salientar que os coeficientes da herdabilidade são válidos para a população considerada e por um determinado tempo (FREITAS, 1981).

\section{Produção de leite}

Algumas estimativas de herdabilidade da pro dução de leite/lactação da raça Holandesa estão apresentạ 
das na Tabela 1 . Os valores variam de 0,11 a 0,57 , com es timativa média próxima de 0,27 .

De acordo com MAIJALA e HANNA (1974),

herdabilidade da produção de leite pode variar com o nivel de produção de rebanho, idade ou ordem de parição das vacas, métodos de estimação, tamanho da amostra e, eventual mente, outros fatores como as regiões geográficas.

No Brasil, CARNEIRO (1953), em vacas mestiças, obteve estimativa da herdabilidade da produção de lei te igual a 0,23, utilizando o método da regressão das filhas em relação às mães. No entanto , NAUFEL (1965/66) analisando dados de vacas holandesas encontrou estimativas de 0,36 e 0,55 pelo método de regressão da primeira lactação das filhas em relação à primeira lactação das mães e pela correlação intraclasse. entre meias-irmãs paternas, respectivamente.

Outros autores, tais como VALE (1977), COSTA (1980) e RIBAS (1981) estimaram a herdabilidade da produção de leite pelo método da correlação intraclasse entre meias-irmãs paternas, em rebanhos de vacas holandesas, encontrando valores de 0,$21 ; 0,42 ; 0,26$, respectivamente.

Segundo FREITAS (1981) o valor estimado para o coeficiente de herdabilidade, a partir de grupos de meias-irmãs paternas, foi $0,37 \pm 0,08$ para produção de lei te. Esse resultado, segundo o autor, é bastante razoável, 
Tabela 1 - Estimativas de herdabilidade da produção de leite/ lactação na raça Holandesa

\begin{tabular}{|c|c|c|c|}
\hline Autor (es) & Local & $\begin{array}{l}\text { Herdabi } \\
\text { lidade }\end{array}$ & Método \\
\hline JOHNSON $(1957)$ & E.U.A. & 0,30 & 1 \\
\hline TABIER e TOUCHBERRY (1959) & E.U.A. & 0,27 & 2 \\
\hline PIRCHNER e LUSH (1959) & E.U.A. & 0,28 & 1 \\
\hline FREEMAN (1960) & E.U.A. & 0,36 & 2 \\
\hline MITCHERLL et alii (1961) & E.U.A. & 0,24 & 2 \\
\hline WILCOX et alii (1962) & E.U.A. & 0,12 & - \\
\hline TOUCHBERRY (1963). & E.U.A. & 0,25 & - \\
\hline WUNDER e MCGILLIARD (1964) & E.U.A. & 0,17 & 2 \\
\hline BERESKIN e FREEMAN (1965) & E.U.A. & 0,22 & 2 \\
\hline NAUFEL $(1965 / 66)$ & Brasil & 0,55 & 1 \\
\hline BLANCHARD et alii (1966) & E.U.A. & 0,29 & 1 \\
\hline BUTCHER et alii (1967). & E.U.A. & 0,28 & 2 \\
\hline GAUNT et alii (1968) & E.U.A. & 0,24 & 1 \\
\hline HOOVEN et alii (1968) & E.U.A. & 0,57 & 2 \\
\hline THOMPSON e LOGANATHAN (1968). & E.U.A. & 0,23 & 1 \\
\hline NORMAN E VAN VLECK (1972) & E.U.A. & 0,32 & - \\
\hline MCDOWELL et alii (1976) & México & 0,11 & 1 \\
\hline CAMOENS et alii (1976c) & Porto Ric & $=0,24$ & 1 \\
\hline LYN e ALLAIRE (1978) & E.U.A. & 0,26 & 1 \\
\hline $\operatorname{costA} \quad(1980)$ & Brasil & 0,42 & 1 \\
\hline MEJIA (1981) & Honduras & 0,18 & 1 \\
\hline RIBAS (1981) & Brasil & 0,26 & 1 \\
\hline FREITAS (1981) & Brasil & 0,37 & 1 \\
\hline NOBRE (1983) & Brasil & 0,30 & 1 \\
\hline
\end{tabular}

1 - Correlação intraclasse entre meias-irmãs paternas.

2 - Regressão mãe-filha.

FONTE: NOBRE (1983), modificada. 
principalmente, se comparado a diversas citações da literatura.

FERREIRA (1983) ao analisar os registros de produção de um rebanho de vacas holandesas encontrou a estimativa da herdabilidade de produção de leite calculada por meio de correlação intraclasse entre meias-irmãs paternas e o respectivo erro padrão, igual a $0,29 \pm$ 0,08. Segundo esșe autor é possível elevar a média de produção de leite através da seleção das vacas e do uso de touros com maior valor genético.

NOBRE (1983) obteve a estimativa da herdabi lidade de produção de leite obtida pelo método da correlação intraclasse entre meias-irmãs paternas a partir de 977 lactações das filhas de 36 reprodutores igual a $0,30 \pm$ 0,09. Segundo o autor, essa estimativa da herdabilidade pạ ra a produção de leite indica que uma seleção dos melhores reprodutores pode conduzir a um melhoramento considerá vel nessa característica.

\section{Duração da lactação}

Em rebanhos de vacas holandesas, McDOWELL et alii (1976a) no México, encontraram uma estimativa em torno de zero, ao estudarem 17.255 períodos de lactação. Resultados semelhantes foram obtidos por CAMOENS et alii (1976), em Porto Rico, também com vacas holandesas. Es- 
ses autores concluíram que a contribuição da variação genética aditiva era muito pequena nesses rebanhos.

$$
\text { Nos Estados Unidos, LYN e ALLAIRE (1978), }
$$

analisando registros de 1.806 vacas holandesas, encontra ram uma estimativa de $-0,03 \pm 0,08$ para a herdabilidade do período de lactação.

$$
\text { RIBAS (1981), no Brasil, estudando } 4.490
$$

lactações das filhas de 90 touros da raça holandesa, estimou a herdabilidade para o período de lactação em 0,03 \pm 0,02, usando o método da correlação, intraclasse entre meias irmãs paternas.

De acordo com NOBRE (1983) o valor encontrado para a estimativa da herdabilidade do periodo de lacta ção foi $0,23 \pm 0,08$. Este valor relativamente alto, sugere que houve uma razoável porção de variação nessa característica devido a efeitos genéticos aditivos. 
3. MATERIAL E METODOS

\subsection{Descrição da propriedade}

Os dados utilizados neste estudo são provenientes do rebanho leiteiro da Fazenda Pinhalzinho, situada no municipio de Araras - S.P., e se referem a a animais de diferentes grupos genéticos provenientes do cruzamento absorvente Holandês preto e branco e Guzerá, nascidos nas anos de 1965 a 1983.

O município de Araras - S.P. situa-se a $47^{\circ} 13^{\prime}$ GW de longitude, a $22^{\circ} 26^{\prime}$ s de latitude com uma alti tude de $620 \mathrm{~m}$.

A Fazenda possui uma ārea de aproximadamente 2.000 ha, tendo como atividades principais a cultura de cana-de-açúcar, laranja e exploração leiteira, sendo que esta última começou em 1960. A partir de 1982 foi iniciada a produção de leite tipo $B$. 
Os dados referentes à precipitação pluviomé trica no período estudado foram obtidos na própria Fazenda, enquanto que a temperatura máxima e mínima e à umidade relativa do ar (Tabelas 1, 2 e 3, do apêndice, respectivamente), na Coordenadoria Regional sul do PLANALSUCAR - Araras - SP.

\subsection{Alimentação e manejo dos animais}

Os animais são criados em regime de pastejo rotativo rotacionado (capim Napier, Pennisetum purpureum, Schum) na época das águas (outubro a abril), e, alimentados, com silagem de milho em cochos colocados nos piquetes na época da seca (maio a setembro).

o milho para silagem é plantado nas āreas de renovação da cuiltura de cana-de-açúcar.

o concentrado é produzido na própria Fazenda e fornecido para as vacas em lactação na proporção de 1 kg para cada 3 litros de leite.

As vacas são levadas ao estābulo presas em canzil, duas vezes por dia, onde recebem o concentrado. A orde nha era feita manualmente num intervalo de $10 \mathrm{~h}$ (às 4:00 h e às 14:00 h) até 1973 passando para ordenha mecânica tipo car relo sendo que eram ordenhadas no mesmo local e mesmo intervalo até março de 1982. A partir dessa data passaram a ser ordenhadas em sala de ordenha tipo espinha de peixe, 
com intervalo entre as ordenhas de $12 \mathrm{~h}$ (às $4: 00 \mathrm{~h}$ e às $16: 00 \mathrm{~h})$.

As vacas no oitavo e as novilhas no sētimo mês de gestação são separadas e mantidas num piquete de parição próximo ao estábulo, onde recebem $4 \mathrm{~kg}$ de concentrado por dia além de todos os cuidados higiênicos sanitários.

As crias são separadas das mães logo após o nascimento. o colostro é fornecido no balde e a ordenha é feita manualmente até oleite da vaca ficar apropriado para o consumo humano.

A suplementação mineral é feita, à vontade, em cochos nos piquetes, além do fornecido pelo concentra do.

Até 1975 a cobertura das vacas e novilhas era feita em regime de monta natural, na qual os animais em cio eram levados aos touros. Aproximadamente metade das vacas e novilhas eram cobertas com touros da raça Holandesa preta e branca e o restante com touros da raça Guzerá. As vacas eram cobertas a partir de 60 dias após o parto e as novilhas quando atingiam mais de $320 \mathrm{~kg}$ de peso vivo.

Com a introdução da inseminação artificial, os touros foram sendo gradativamente eliminados. O ūltimo touro da raça Guzerá foi usado até o final de 1979, res- 
tando apenas um touro Holandês preto e branco, para ser usạ do nas vacas ou novilhas que repetem mais de três inseminações. A partir de 1980 passou-se a usar sêmen de touros pro vacios de origem americana.

\subsection{Descrição dos dados.}

Foram compilados, a partir da escrituração zootécnica da fazenda, todos os registros da produção de leite por lactação (PL) e da duração da lactação (DL) obtị dos de 421 vacas, perfazendo um total de 1.529 lactações no período de 1970 a 1983 inclusive, tendo-se eliminado apenas os casos de aborto e as ocorrências patológicas que puderam ser identificadas. A produção de leite foi controlada a cada quinze dias, pela própria Fazenda.

Nesse conjunto de dados foram identificadas as seguintes fontes de variação:

Ano de parição: os dados são relativos ao período de quatorze anos, englobando os anos de 1970 a 1983 . o ano de 1983 inclui apenas as lactações encerradas nesse ano, uma vez que a coleta dos dados foi feita em janeiro de 1984, enquanto que o ano de 1970 inclui lactações dos anos 68 e 69 em número pequeno.

Epoca de parição: as lactações se distribuem em todos os meses, porêm, para fins de anālise foram 
consideradas quatro épocas de parição relativas aos trimestres civis do ano.

Ordem do parto: o conjunto de lactações com preende oito ordens de parto, sendo que a ordem oito englo ba além da oitava parição as ordens superiores.

Grupo genētico: as vacas do rebanho provenientes do cruzamento Holandês preto e branco x Guzerá se distribuem em cinco grupos genéticos a saber: 1/2 HPB; 1/2 Gu; 3/4 HPB; 7/8 HPB; 15/16 HPB e 31/32 HPB.

Idade da. vaca no parto: essa variável expressa em meses foi usada como variável parià PL e DL.

Touro: as. 384 vacas eram filhas de 24 reprodutores. Para fins de análise, considerou-se apenas os touros que tinham mais de cinco filhas no rebanho. Desse modo, na análise dos parâmetros genéticos o conjunto de dạ dos reduziu para 1.374 lactações devido à eliminação dos registros relativos aos touros com menos de cinco filhas.

\subsection{Análise estatistica}

Tendo em vista os objetivos deste trabalho, os dados da produção de leite e duração da lactação foram anạ lisados, pelo método dos quadrados mínimos (HARVEY, 1972, 1979), de acordo com os seguintes modelos estatísticos: 


\section{Modelo}

Avaliar a magnitude e significância dos efeitos do ano de parição, época de parição, grupo genético, bem como da regressão linear e quadrática da idade da vaca no parto sobre a produção de leite (PL) e duração da lactação (DL). Nessa análise, as somas de quadrados relativas ao ano de parição e ao grupo genético foram decompostas nos componentes ortogonais do 19 ao 59 grau, de acordo com a regressão polinomial.

Foram usadas as 1.529 lactações para completar esta análise estatística.

\section{Modelo}

Avaliar os efeitos do ano de parição, época de pariçãc, grupo genético, regressão linear e quadrática da idade no parto e regressão linear e quadrática da duração da lactação sobre a produção de leite. Do mesmo modo que no 19 modelo foram realizadas as decomposições da soma de quadrados do ano de parição e do grupo genético. Para esta análise utilizou-se $\odot$ conjunto completo de dados.

39. Modelo

Similar ao 19 modelo, apenas incluiu o efe to aleatório de touros, para se obter o respectivo compo - 
nente de variância e estimar a herdabilidade da produção de leite e da duração da lactação. Nesta análise foram usa das 1.374 lactações, devido à eliminação dos touros com menos de cinco filhas.

\subsection{Estimativa da herdabilidade.}

A partir do componente de variância referen te aos touros, obtem-se a estimativa da herdabilidade da PL e DL, pelo método das meias-irmãs paternas, conforme se ségue:

$$
h^{2}=\frac{\sigma^{2} t}{\sigma^{2} t+\sigma^{2} e}
$$

Onde: $\sigma^{2} t=$ componente de variância referente aos touros $\sigma^{2} e=$ componente de variância relativo ao resíduo obtidos a partir do modelo 3 da análise.

A estimativa da herdabilidade e o respectivo erro de estimação é fornecido diretamente pelo programa utilizado na anáaise dos dados (HARVEY, 1979). 
4. RESULtAdOS E DISCUSS ̃̃O

4.1. Produção de leite

Baseado nos registros de 1.529 lactações não corrigidas, a média geral de produção de leite e o respectivo desvio padrão ao longo dos anos estudados foi $3.007,47 \pm 1.247,61 \mathrm{~kg}$, com um coeficiente de variação da ordem de 41,48\%. Este coeficiente foi superior aos encontrados por NAUFEL (1965/66), NEIVA (1979), COSTA (1980), ME JIA (1981), RIBAS (1981) e FERREIRA (1983)， respec tivamente, 33\%, $26,1 \%, 17,6 \%, 18,5 \%, 17,5 \%$ e 25\%. Uma das razões do alto coeficiente é que os dados não foram seleciona dos, como tem sido feito por alguns autores, e, existia no rebanho uma heterogeneidade muito grande em termos de produção, assim como, o manejo e a alimentação também não foram uniformes ao longo dos anos. 
Com relação à média de produção de leite esta se apresentou superior aos $1.938 \mathrm{~kg}$ encontrados por NAUFEL $(1965 / 66)$ e $2.095,7 \mathrm{~kg}$ e $1.982 \mathrm{~kg}$ encontrados por MAHADEVAN (1956) e WILSON e HOUGHTON (1962), respectivamente, sendo, no entanto inferior àquelas encontradas por RIVEROS (1979), COSTA (1980), RIBAS (1981) e FERREIRA (1983) da ordem de $4.136,99,3.935,9,5.085,65$ e $3.714,5 \mathrm{~kg}$, respectivamente e,também, inferior à média de $4.757 \mathrm{~kg}$ de leite publicada pela Associação Brasileira de Criadores de Bovinos da Raça Holandesa, de acordo com o resumo estatístico do Ministério da Agricultura (1978/79), referentes a 4.966 registros, encerrados em 1977/78. Médias supe riores às encontradas neste estudo foram tambēm relatadas por BRANDT et alii (1966), $5.521 \mathrm{~kg}$ de leite, e por MILLER et alii (1968), $5.587 \mathrm{~kg}$ obtidas em 24.636 lactações. Da mesma forma, em mais de 3 milhões de lactações de vacas holandesas, nos Estados Unidos, NORMAN et alii (1974) encontraram uma média de $5.851 \mathrm{~kg}$ de leite.

A média de produção de leite encontrada assemelhou-se à obtida por NEIVA et alii (1979) que foi de $3.003,52 \mathrm{~kg}$ também em rebanho com diferentes grupos genéticos de raça Holandesa.

A análise da variância e os testes de significância da produção de leite incluindo os efeitos de ano de parição, época, grau de sangue e idade da vaca 
na parição estão apresentados na Tabela 4 do apêndice.

Ano de parição

o ano de parição apresentou efeito altamente significativo $(P<0,01)$ sobre a produção de leite. A Tabela 2 contem as médias de produção de leite ao longo dos anos, as quais são ilustradas graficamente na Figura 1.

Em termos gerais, houve uma tendência no sen tido de aumentar a produção de leite com o passar dos anos. De fato, o componente linear foi altamente significativo, porém, responsável por cerca de 33,92\% da soma dos quadrados do ano de parição (Tabela 4 do apêndice).

A queda de produção observada no ano de 1973, não pode ser atribuída a fatores climáticos e seus efeitos diretos e indiretos sobre a performance conforme análi se da Tabela 1, do Apendice relativas aos dados me teorológicos. Entretanto, é provável que ela tenha ocor rido em consequência da mudança de ordenha manual para orde nha mecânica. A partir desta data existe uma nitida tendência para o aumento da produção de leite ao longo dos anos (Figura 1). Este aumento na produção de leite ao longo dos anos foi também observado por MAHADEVAN (1956), no Ceilão, ao trabalhar com raças leiteiras especializadas. Tal aumento, foi observado, também por MCDOWELL et alii (1975, 1976a) ao trabalhar com 48 rebanhos de vacas holandesas. 
Tabela 2 - Média de produção de leite $(\mathrm{kg})$ e o número de observações, segundo o ano de parição

\begin{tabular}{|c|c|c|}
\hline Ano & $\begin{array}{c}\text { Nümero de } \\
\text { observações }\end{array}$ & $\begin{array}{l}\text { Produção de leite } \\
\text { 土 erro da média }\end{array}$ \\
\hline 1970 & 53 & $3049,75 \pm 156,32$ \\
\hline 1971 & 37 & $2692,07 \pm 182,77$ \\
\hline 1972 & 55 & $2379,07 \pm 150,62$ \\
\hline 1973 & 71 & $2217,94 \pm 131,66$ \\
\hline 1974 & 98 & $2664,61 \pm 112,32$ \\
\hline 1975 & 89 & $2747,99 \pm 118,30$ \\
\hline 1976 & 112 & $2689,00 \pm 104,86$ \\
\hline 1977 & 139 & $2715,25 \pm 94,47$ \\
\hline 1978 & 123 & $3025,38 \pm 101,23$ \\
\hline 1979 & 152 & $3437,69 \pm 91,10$ \\
\hline 1980 & 175 & $3172,36 \pm 85,53$ \\
\hline 1981 & 185 & $3144,13 \pm 83,60$ \\
\hline 1982 & 184 & $3369,48 \pm 85,22$ \\
\hline 1983 & 56 & $2405,79 \pm 155,44$ \\
\hline
\end{tabular}




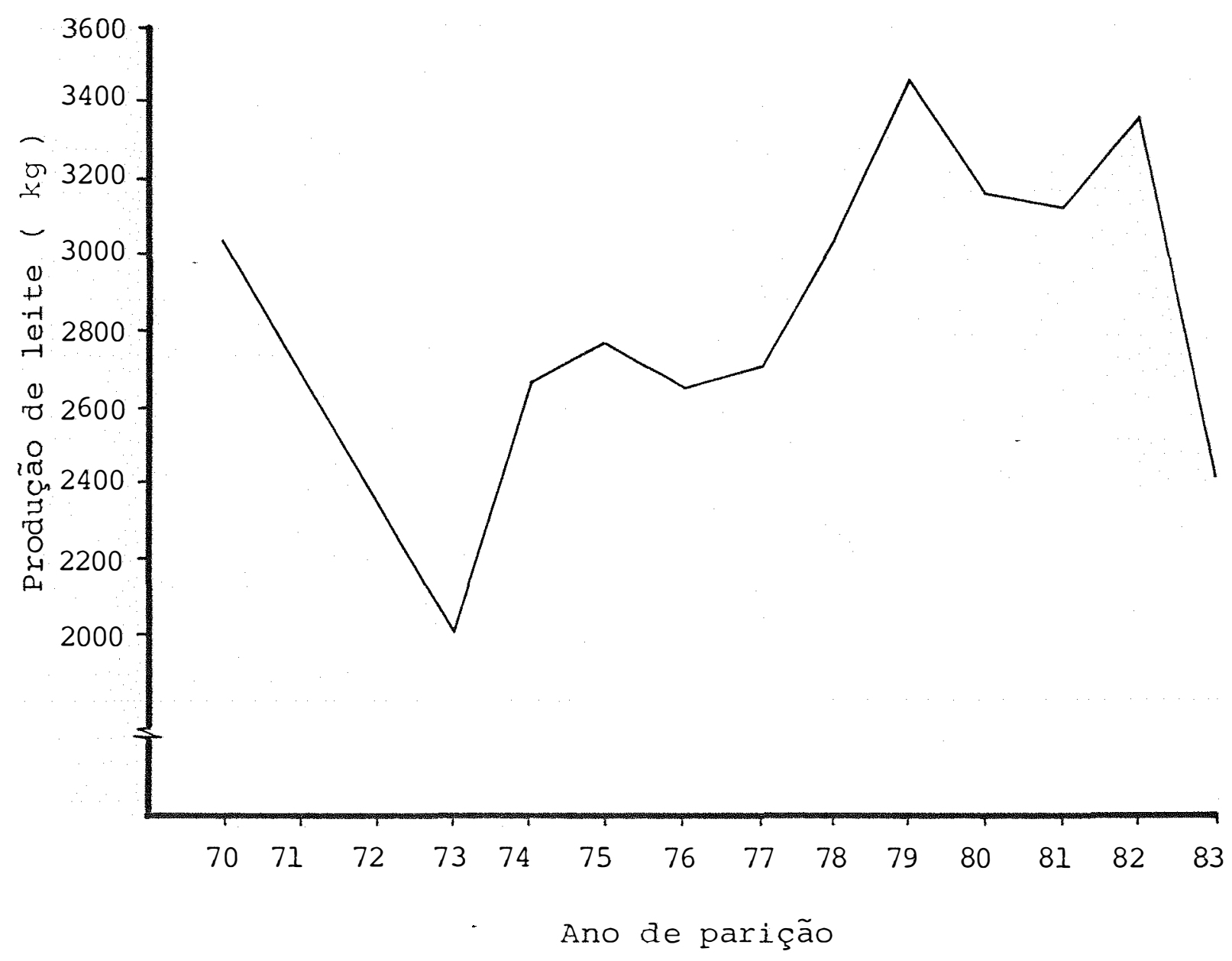

Figura 1 - Média de produção de leite segundo o ano de parição 
No Brasil este mesmo efeito foi,também, detectado por MANDUJANO (1979), NEIVA (1979), COSTA. (1981), MEJIA (1981), FREITAS (1981) e FERREIRA (1983).

Por outro lado, nos Estados Unidos, SPECHNT, MCGILLIARD (1960), MILLER e HOOVEN (1969) não encontraram efeito significativo de ano sobre a produção de leite. Ao contrário, CAMOENS et alii (1976), em Porto Rico, ao trabalharem com 62 rebanhos holandeses observaram uma marcante diminuição da produção de leite ao longo dos anos.

\section{Epoca de parição}

Não houve efeito significativo da época de parição sobre a produção de leite. A época foi responsável por apenas 0,39\% da soma de quadrados totais (Tabela 4 do Apêndice ).

$$
\text { As médias de produção de leite nas quạ }
$$
tro épocas consideradas estão apresentadas na Tabela 3. Tabela 3 - Média de produção de leite e o nümero de observações, segundo a época de parição

\begin{tabular}{lcc}
\hline Epoca de parição & $\begin{array}{c}\text { Número de } \\
\text { observações }\end{array}$ & $\begin{array}{l}\text { Produção de leite } \\
\pm \text { erro da média }\end{array}$ \\
\hline Janeiro-Março & 353 & $2741,75 \pm 61,98$ \\
Abril-Junho & 393 & $2854,77 \pm 59,00$ \\
Julho-Setembro & 420 & $2951,88 \pm 58,76$ \\
Outubro-Dezembro & 363 & $2797,47 \pm 60,70$ \\
\hline
\end{tabular}


Mesmo não resultando em efeito significativo conforme a Tabela 3 , as menores produções foram encontradas entre os meses de outubro a dezembro $(2.797,47 \pm 60,70 \mathrm{~kg})$ e os de janeiro a março $(2.741,75 \pm 61,98 \mathrm{~kg})$, coincidindo com a estação quente e úmida. Estes resultados não concordam com o encontrado pela maioria dos pesquisadores, nos Estados Unidos, como BROWN et alii (1960), MILLER et alii (1970), HARDIE et alii (1978), os quais. notaram efeito significativo da época de parição, sendo que as methores produções ocorriam no inverno. Do mesmo modo, no Brasill, diversos autores têm verificado que as lactações de vacas da raça Holandesa, quando iniciadas na estação seca e fria (abril a setembro), tem apresentado um incremento na produção de leite (RIVEROS, 1979; NEIVA, 1979; MANDUJANO, 1979; COSTA, 1980; RIBAS, 1981; FERREIRA, 1983; NOBRE, 1983).

Resultados semelhantes ao encontrado neste trabalho foram obtidos por OLIVEIRA (1973), DIAS et a $i$ i. (1974), LOBO (1980) e PRIMO et alii (1980).

O motivo pelo qual não ocorreu efeito signi ficativo da época de parição sobre a produção de leite, se deve provavelmente ao fato de tratar-se de um rebanho de produção relativamente baixa, não sofrendo tanto com isto as conseqüências causadas pela adversidade do clima, qualidade e quantidade dos alimentos e modificações do mane- 
jo, por que passam as vacas nas diferentes épocas dos anos.

Idade da vaca e ou ordem de parição

Baseado nos registros de 1.529 lactações

a idade média das vacas na parição e o respectivo desvio padrão foi $69,93 \pm 33,91$ meses.

Conforme mostrado na Tabela 4 do Apêndice, a idade da vaca apresentou efeito linear e quadrático altamente signi ficativo $(P<0,01)$, sobre a produção de leite, respondendo por cerca de $0,82 \%$ e 4,15\% dá soma de quadrados totais da produção de leite para aqueles efeitos, respectiva mente. Na Figura 2 está representada a curva de resposta da produção de leite em função da idade da vaca, em meses, na parição, e na Tabela 4 a produção de leite estimada em função da idade da vaca e fatores de correção multiplicatị vos para idade adulta.

A produção máxima ocorreu na faixa etāria dos 72 aos 90 meses. Tais valores estão próximos daqueles encontrados na literatura. LUSH e SHRODE (1950), MILLER (1964), GACULA et alii (1968), NORMAN et alii (1974), MC DOWELL (1976a) e CAMOENS et alii (1976), que encontraram na raça Holandesa 73 a 102 meses, 80 a 100 meses, 82 a 85 meses, 78 a 85 meses, 70 a 80 meses e 72 meses de idade, respectivamente. No Brasil, esta produção máxima foi ob- 
Tabela 4 - Produção de leite estimada em função da idade da vaca e fatores de correção multiplicativos para a idade adulta

\begin{tabular}{|c|c|c|}
\hline $\begin{array}{c}\text { Idade da vaca } \\
\text { (meses) }\end{array}$ & $\begin{array}{c}\text { Produção estimada } \\
(\mathrm{kg})\end{array}$ & Fator de correção \\
\hline 30 & 2527,89 & 1,1982 \\
\hline 36 & 2639,51 & 1,1475 \\
\hline 42 & 2737,13 & 1,1066 \\
\hline 48 & 2820,78 & 1,0738 \\
\hline 54 & 2890,43 & 1,0479 \\
\hline 60 & 2946,09 & 1,0281 \\
\hline 66 & 2987,76 & 1,0138 \\
\hline 72 & 3015,44 & 1,0044 \\
\hline 78 & 3029,13 & 1,0000 \\
\hline 84 & 3028,83 & 1,0000 \\
\hline 90 & 3014,55 & 1,0047 \\
\hline 96 & 2986,27 & 1,0143 \\
\hline 10.2 & 2944,00 & 1,0288 \\
\hline 108 & 2887,75 & 1,049 \\
\hline 114 & 2817,50 & 1,075 \\
\hline 120 & 2733,27 & 1,108 \\
\hline 126 & 2635,04 & 1,149 \\
\hline 132 & 2522,83 & 1,200 \\
\hline 138 & 2396,62 & 1,264 \\
\hline 144 & 2256,43 & 1,342 \\
\hline
\end{tabular}




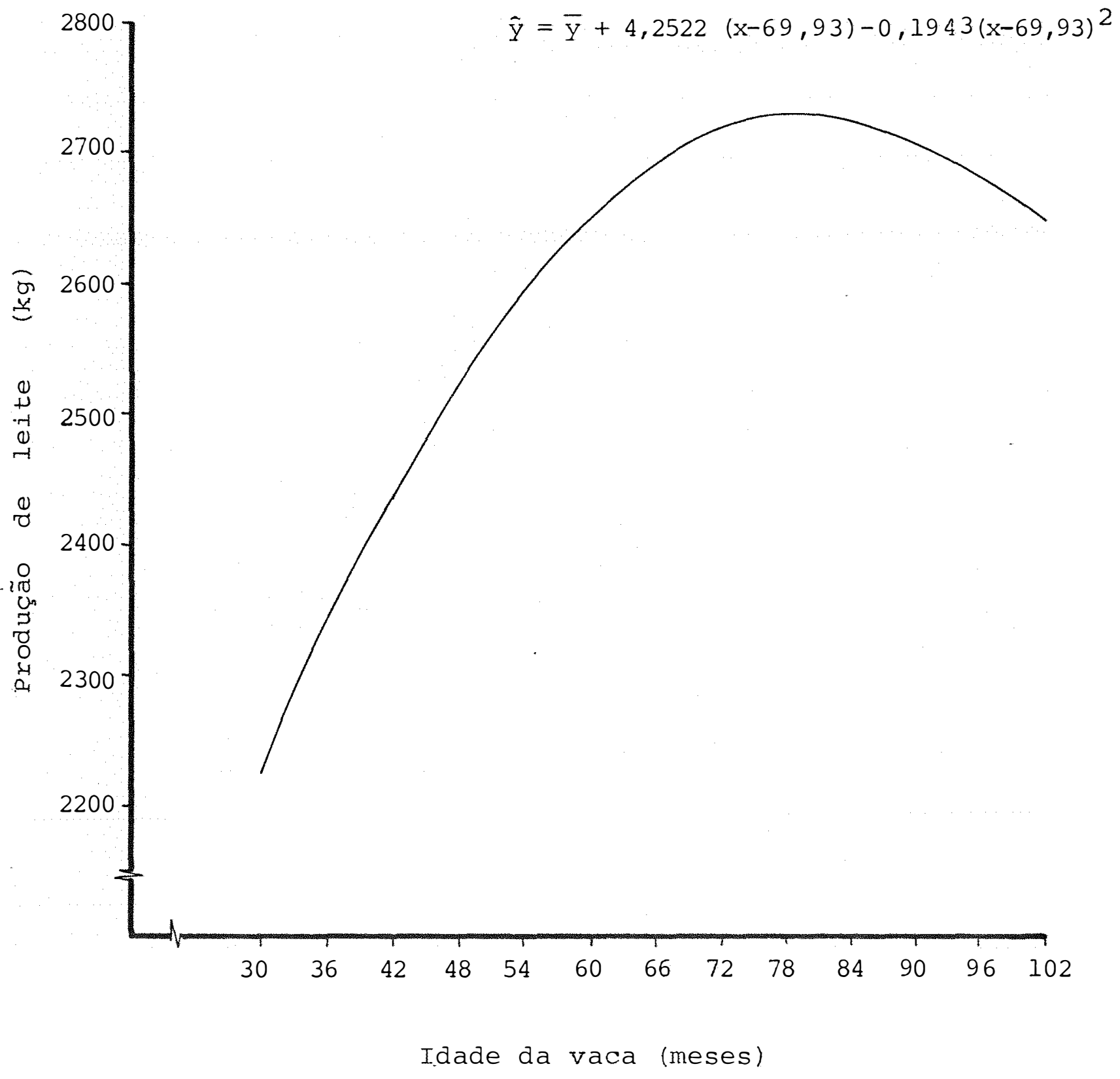

Figura 2 - Efeito da idade da vaca sobre a produção de leite 
tida na faixa dos 63 a 96 meses, segundo NAUFEL (1965/66); 85 a 96 meses de acordo com OLIVEIRA (1973); 84 a 90 meses conforme COSTA (1980) e 85 meses segundo RIBAS (1981). No entanto, a faixa etária obtida no presente estudo: está abaixo dos valores relatados por FERREIRA (1983) e NOBRE (1983) que encontraram 108 a 120 e 132 meses de idade, respectivamente.

As razões para o aumento da produção com a idade da vaca até a maturidade fisiológica podem ser explicadas de acordo com as mudanças na anatomia e fisiologia do organismo e da glândula mamāria (TUCKER, 1979).

No rebanho em estudo a produção na maturidạ de fisiológica equivaleu à cerca de 19,8\% a mais da observada na idade de 30 a 36 meses.

Levando em conta que os fatores de correção apresentados na Tabela 4 são específicos para o rebanho, eles não diferem em essência daqueles apresentados por SCHMIDT E VAN VLECK (1974), FREITAS (1981), sendo, no entarto bastante distintos dos obtidos por RIBAS (1981), FERREIRA (1983) e NOBRE (1983).

Grupo genētico

O grupo genético das vacas apresentou efeito altamente significativo $(P<0,01)$ sobre a produção 
de leite (Tabela 4 do Apēndice). Os componentes ortogonais linear, cúbico e quártico foram significativos, sendo que o componente linear apresentou maior importância, pois explica 66,7\% da soma dos quadrados do grupo genético (Tabela 4 do Apêndice).

Na Tabela 5 e na Figura 3 estão apresentạ das as médias da produção de leite de acordo com o grupo genético das vacas.

Tabela 5 - Média de produção de leite e o número de observạ ções, segundo o grupo genético

\begin{tabular}{lll}
\hline $\begin{array}{c}\text { Grupo Genético } \\
*\end{array}$ & $\begin{array}{c}\text { Número de } \\
\text { observações }\end{array}$ & $\begin{array}{l}\text { Produção de leite } \\
\pm \text { erro da média * }\end{array}$ \\
\hline $1 / 2 \mathrm{H}: 1 / 2 \mathrm{GU}$ & (1) 155 & $2254,50 \pm 92,72 \mathrm{a}$ \\
$3 / 4 \mathrm{H}: 1 / 4 \mathrm{GU}$ & (2) 356 & $2897,33 \pm 60,60 \mathrm{~b}$ \\
$7 / 8 \mathrm{H}: 1 / 8 \mathrm{GU}$ & (3) 455 & $2790,13 \pm 55,70 \mathrm{~b}$ \\
$15 / 16 \mathrm{H}: 1 / 16 \mathrm{GU}$ & (4) 281 & $2931,10 \pm 71,71 \mathrm{~b}$ \\
$31 / 32 \mathrm{H}: 1 / 32 \mathrm{GU}$ & (5) 282 & $3309,26 \pm 72,81 \mathrm{bc}$ \\
\hline
\end{tabular}

* = H: Holandès GU: Guzerá

** = Médias seguidas de letras iguais não diferem entre si pelo Teste de Tukey, aproximado.

O aumento da contribuição da raça Holandesa determinou aumento significativo na produção de leite por lactação. A comparação das médias pelo Teste de Tukey indica que não houve diferenças significativas na produção de leite dos grupos 3/4H:1/4GU; 7/8H:1/8GU e. 15/16H:1/16GU . 


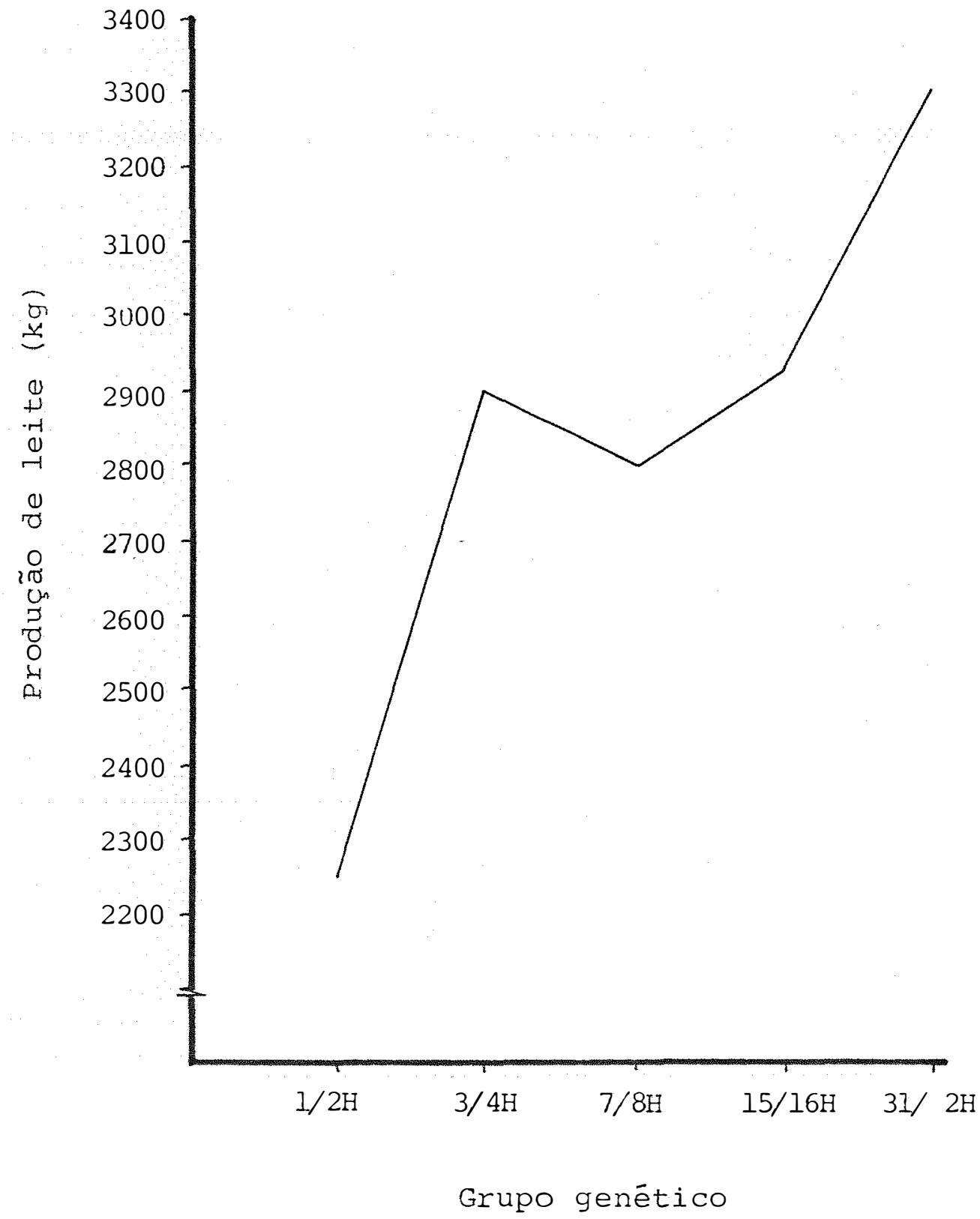

Figura 3 - Média de produção de leite segundo o grupo genético das vacas 
No manejo deste rebanho as vacas de baixa produção sofreram maior intensidade de descarte, a partir dos resultados da primeira lactação. Apesar deste aspecto, que, evidentemente, contribui para distorcer em parte as comparações entre os diferentes grupos genēticos, fica evidenciado a importância deste programa de cruzamento absorvente no melhoramento genético da produção de leite.

Estes resultados estão de acordo com os encontrados por KASSIR et alii (1969), no Iraque e ALVES NE TO (1967), LOBO e DUARTE (1977), NEIVA et alii (1979), FERREIRA (1983) todos no Brasil, os quais observaram efeito significativo do grupo genético sobre a produção de leite, no qual ocorreu um incremento na produção com o aumento de genes da raça Holandesa.

Ao contrārio, RIVEROS (1979) e MADALENA et alii (1983) não encontraram efeito significativo em grupos genéticos sobre a produção de leite.

Os diferentes resultados relatados na literatura podem ser justificados pela existência de uma intera ção significativa entre grupo genético e nível do sistema de produção: sobre a produção de leite (MADALENA et alii, 1982). Segundo esses autores, quando o sistema é conduzido como de alto nível de tecnologia, a tendência geral consiste no aumento de produção com a maior constituição genética 
das raças especializadas. Tendências diferentes são constatadas nos sistemas de baixo nível de tecnologia.

Em vista destes argumentos fica evidenciado que o sistema de produção adotado no rebanho sob estudo é suficientemente adequado para permitir a expressão do maior potencial genético das vacas com maior contribuição dä raça Holandesa.

\subsection{Período de lactação}

A média geral e o respectivo desvio padrão da duração da lactação referente a 1.529 registros de produ ção foram 273,72 $\pm 69,93$ dias com um coeficiente de varia ção da ordem de 31,46\%. Este coeficiente está um pouco acima do encontrado pelos pesquisadores OLIVEIRA (1973), MANDU JANO (1979) e NOBRE (1983) que encontraram 26,5\%, 28,8\% e $27,0 \%$ respectivamente. Por outro lado, está muito acima do observado por FREITAS (1981) e RIBAS (1981) que foram $14 \%$ e 15,5\%, respectivamente. Já KASSIR et alii (1969) obtí veram um coeficiente de variação similar da ordem de 31,5\%. O alto coeficiente de variação encontrado é devido ao fato dos dados usados não terem sofrido nenhum tipo de seleção.

A média geral do período de lactação deste rebanho, constituído de vacas com diferentes grupos genéticos é bem menor do que aquelas obtidas no Brasil em vários rebanhos de vacas holandesas, por OLIVEIRA (1973), VA- 
LE e NALE (1978), MANDUJANO (1979), NEIVA (1979), FREITAS et alii (1980), FREITAS (198I), RIBAS (1981), que foram $329,313,324,301,301,317$ e 306,5 dias de lactação, respectivamente. Entretanto, NOBRE (1983), com rebanho de dife rentes, grupos genéticos obteve um período de lactação inferior, 245 dias. Todavia BRANDT et alii (1966) e BRANTON et alii (1967), em rebanhos de vacas holandesas, nos Estados Unidos, encontraram períodos próximosdo desejado, 300 e 304 dias de lactação, respectivamente, porque refletem a ex pectativa dos produtores de se obter uma lactação e uma cria por ano através do período médio de 305 dias de lactação. Lactações acima desse período não são desejāveis porque ao final da mesma, a produção é relativamente baixa e reduz a eficiência reprodutiva do rebanho através de longos intervalos entre partos.

A análise da variância e os testes de signi ficância do período de lactação incluindo os efeitos de ano de parição, época, grupo genético e idade da vaca na parição estão apresentados na Tabela 5 do Apêndice, enquanto que a análise incluindo o efeito da ordem de parição, além dos outros efeitos está na Tabela 6 do Apêndice.

\section{Ano de parição}

O ano de parição apresentou efeito altamente significativo $(\mathrm{P}<0,01)$ sobre a duração da lactação. A 
Tabela 6 contēm as médias da duração da lactação ilustradas graficamente na Figura 4.

Tabela 6 - Duração média da lactação, erro da média e nūmero de observações segundo o ano de parição

\begin{tabular}{|c|c|c|c|}
\hline Ano & $\begin{array}{c}\text { Nümero de } \\
\text { observações }\end{array}$ & $\begin{array}{r}\text { Duração da } \\
\pm \text { erro }\end{array}$ & $\begin{array}{l}\text { Ia lactação } \\
\text { da média }\end{array}$ \\
\hline 1970 & 53 & $343,50 \pm$ & $=11,67$ \\
\hline 1971 & 37 & $293,29 \pm$ & $=13,64$ \\
\hline 1972 & 55 & $307,87 \pm$ & $=11,24$ \\
\hline 1973 & 71 & $312,60 \pm$ & $=9,82$ \\
\hline 1974 & 98 & $284,98 \pm$ & 8,37 \\
\hline 1975 & 89 & $270,57 \pm$ & 8,79 \\
\hline 1976 & 112 & $247,90 \pm$ & 7,81 \\
\hline 1977 & 139 & $262,87 \pm$ & 7,04 \\
\hline 1978 & 123 & $259,31 \pm$ & 7,53 \\
\hline 1979 & 152 & $261,12 \pm$ & 6,80 \\
\hline 1980 & 175 & $255,97 \pm$ & 6,34 \\
\hline 1981 & 185 & $245,88 \pm$ & 6,19 \\
\hline 1982 & 184 & $276,35 \pm$ & 6,31 \\
\hline 1983 & 56 & $218,31 \pm$ & 11,49 \\
\hline
\end{tabular}

Em termos gerais houve uma tendência no sen tido de reduzir a duração da lactação no decorrer dos anos. De fato, o componente linear foi altamente significativo e explicou cerca de 46,95\% da soma de quadrados do ano de 


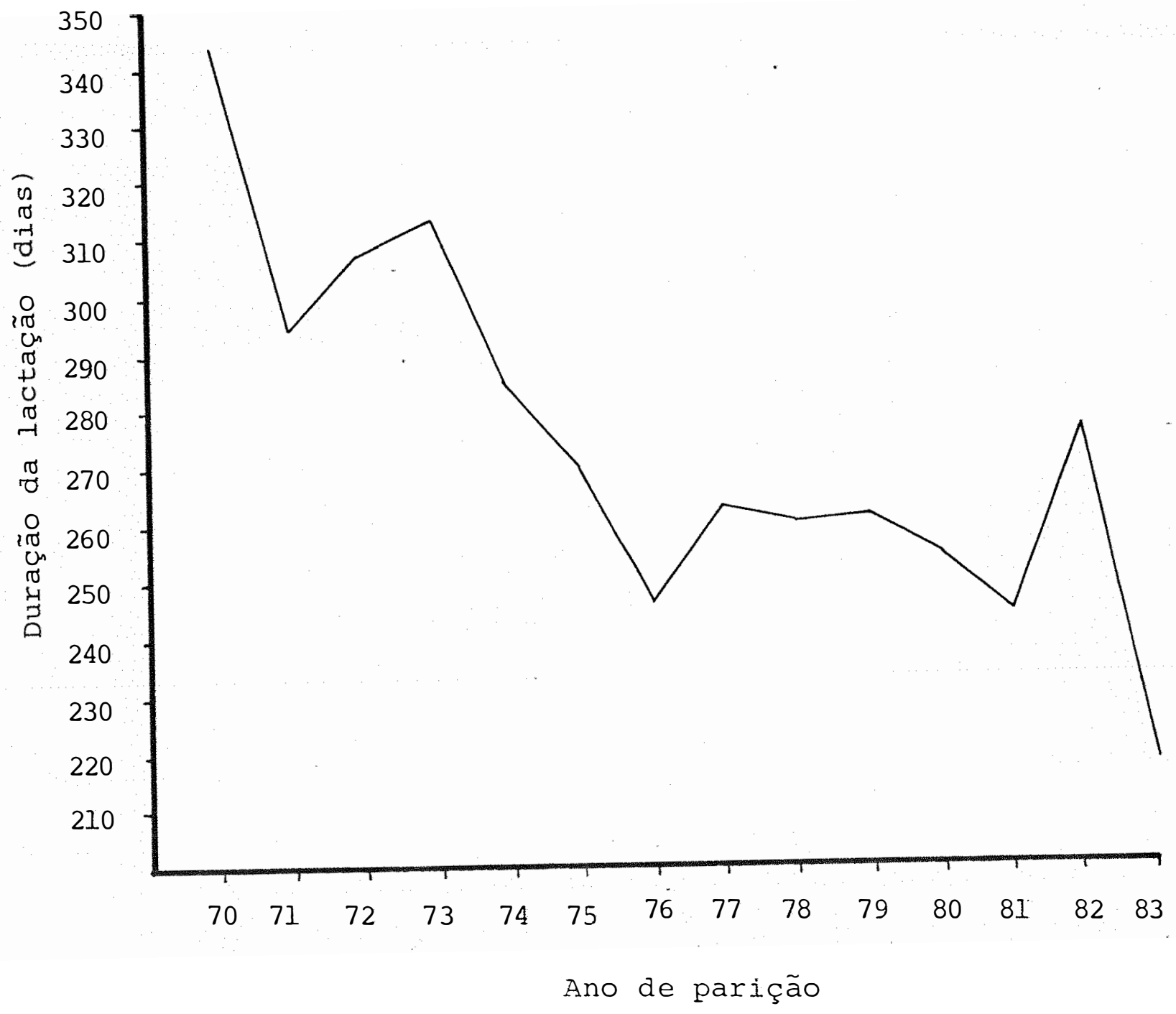

Figura 4 - Duração média da lactação segundo o ano de parição 
parição (Tabela 5 do Apêndice). Estes resultados são contrários aos obtidos por ALVES NETO et alii (1967) que observaram aumento do período de lactação com o decorrer dos anos, variando de 213,5 dias em 1945 para 284,2 dias en 1966.

MANDU JANO (1979), FREITAS (1981), RIBAS (1981) e NOBRE (1983). tambēm encontraram efeito altamente significativo do ano de parição sobre a duração da lactação. Em outros países, resultados semelhantes foram obtidos por KIWUWA (1974), MCDOWELL et alii (1976a), onde ocorreu um aumento da duração da lactação no decorrer dos anos estudados. Os resultados obtidos concordam com os de CAMOENS et arii (1976"), no México, onde se deu uma diminuição do período ao longo dos anos em estudo.

Os períodos de lactações mais altos obtidos nos primeirosquatro anos em estudo (1970 a 1973) podem ser atribuidos em parte ao fato de que neste período a ordenha era feita manualmente, e sob estas condições muitas vacas ficavam por mais tempo produzindo poucos litros por dia (1 a 4), até que a mesma secasse por si só ou atingisse o 70 mês de gestação. A partir de 1973, ocorreram alterações no manejo como, mudança do sistema de ordenha manual para mecânica, aumento de 138,4\% do número de animais em ordenha entre os anos 19.73 a 1981, além da qualidade e quantidạ de dos alimentos não acompanhar adequadamente a evolução do rebanho. Em 1982 ocorreu um aumento acentuado $(276,35$ 
diasl quando comparado com os anos anteriores, devido, principalmente,'a melhora da qualidade e quantidade da alimenta ção fornecida aos animais tanto da silagem, como dos pastos. Também melhorou o manejo o descarte das vacas que vem sendo realizado ao longo dos anos, principalmente, a partir do ano de 1981, que è em torno de 30\%. o período de lactação curto constitui um dos critérios adotados para o descarte.

A menor duração da lactação encontrada no ano de 1983 (Tabela 6) decorreu do fato de que na época da coleta de dados (dezembro/83 e janeiro/84), foram computadas somente aquelas iniciadas no presente ano, mas que já tivessem a lactação terminada por ocasião da computação dos dados. Com isto, a maioria das lactações comnutadas eram exatamente aquelas de período de lactaçäo mais curto.

Epoca ou estação de parto

Não houve efeito significativo da ëpoca de parição sobre o período de lactação. Na realidade a época foi responsável por apenas $0,31 \%$ da soma de quadrados totais (Tabela 5 do Apêndice).. As médias da duração da lactação nas quatro épocas consideradas estão apresentadas na Tabela 7 . 
Tabela 7 - Duração média da lactação, erro da média e o número de observações por época de parição

Epoca de parição

Número de observações
Duração da lactação \pm erro padrão

$\begin{array}{lcc}\text { Janeiro-Março } & 353 & 273,59 \pm 4,63 \\ \text { Abril-Junho } & 393 & 276,14 \pm 4,40 \\ \text { Julho-Setembro } & 420 & 280,75 \pm 4,38 \\ \text { Outubro-Dezembro } & 363 & 266,84 \pm 4,53\end{array}$

Apesar de não ser significativo, os menores períodos de lactação foram encontrados entre os meses de ou tubro a dezembro $(266,84 \pm 4,53)$ e os de janeiro a março $(273,59 \pm 4,63$ dias), coincidindo com a estação quente e úmida. Estes resultados estão de acordo com o encontrado por CAMOENS et alii (1976), em Porto Rico, MANDUJANO (1979), no Brasil, que não observaram efeito significativo da época da parição sobre a duração da lactação. Entretanto, são contrários aos encontrados pela maioria dos pesquisadores que observaram efeito significativo desta causa de variân cia, ALVES NETO (1967), GOIC (1974), KIWUWA (1974), BRANTON et alii (1974), NOBRE (1983), de tal modo que os períodos de lactações mais curtos ocorreram nas vacas que iniciaram a lactação nas épocas mais quentes do ano, no qual o excesso de calor (acima de $28^{\circ} \mathrm{C}$ ) estaria interferindo no consumo de alimento pelas vacas, conseqüentemente, na duração da lacta 
ção. Já,segundo outros autores tal diminuição seria devido ao fato que nesta época, principalmente no Brasil, as vacas são alimentadas basicamente em regime de pasto, alimento geralmente inferior quando comparado à silagem ou cultụ ras de inverno, alimentos estes que são normalmente forneci dos aos animais na estação seca e fria (abril a setembro), pois os pastos nesta época, praticamente, são improdutivos. O efeito da época de parição sobre a duração da lactação depende do nível de produção. Tal efeito é tanto maior quan do maior for a dependência das pastagens. Portanto, no presente caso, como o nível de tecnologia empregada é mais alto, justifica-se a ausência do efeito significativo da época da parição.

Idade da vaca e ou ordem de parição

Conforme o mostrado na Tabela 5 do Apêndice a idade da vaca apresentou efeito linear altamente significativo $(P<0,01)$ sobre a duração da lactação. Na Figura 5 es tá apresentada a curva de resposta da duração da lactação em função da idade, em meses, das vacas na parição.

De acordo com o apresentado na Tabela 6 do Apêndice, foi efetuado um estudo do efeito da ordem da lactação so bre a duração da mesma. De modo similar ao efeito da idade da vaca, a ordem do parto apresentou um efeito linear $(P<0,01)$ signifi cativo sobre a duração da lactação (Tabela 6 do Apêndice). 


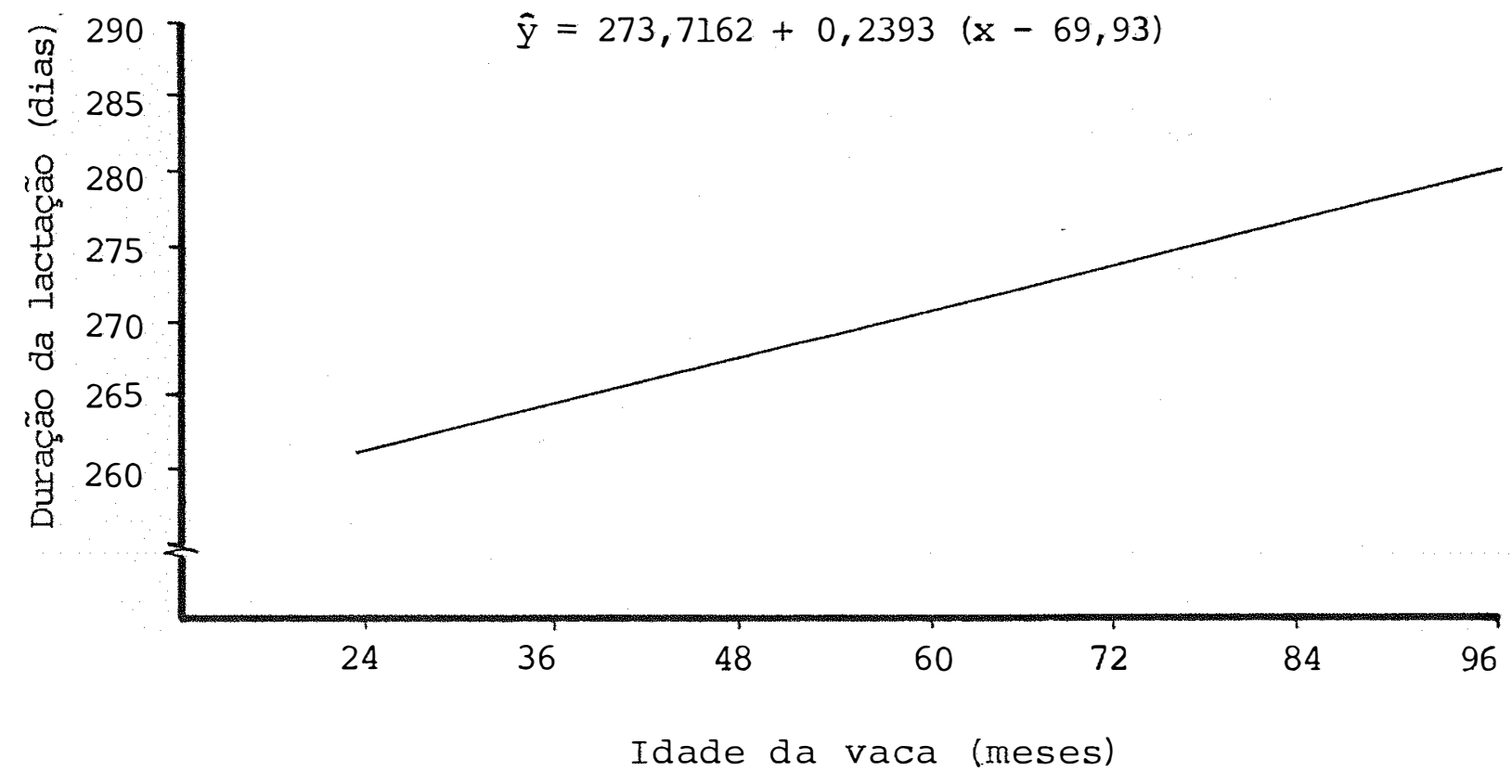

Figura 5 - Efeito da idade da vaca sobre a duração da lactação 
As médias do período de lactação de acordo com a ordem de parição estão apresentadas na Tabela 8 e ilustradas na Figura 6. De acordo com estes resultados ocor re aumento da duração da lactação à medida que aumenta a or dem, diminuindo a partir da oitava.

Os resultados encontrados $(272,03$ dias na segunda lactação e 284,28 dias na quinta lactação) estão mui to aquém daqueles obtidos por VALLE e NALI (1978) que foi maior na segunda lactação $(322,2$ dias) do que na quinta lac tação (314,5 dias). Também foram contrários aos obtidos por ALVES NETO (1967), SCHAEFFER e HENDERSON (1972), BRANTON et alii (1974), RIBAS (1981)e NOBRE (1983), os quais verifí caram efeito significativo $(P<0,01)$ da ordem de parição sobre a duração da lactação, de forma linear, onde os maiores períodos de lactação ocorriam nas vacas mais jovens, decrescendo com o avanço da idade ou ordem de parição. Toda via, outros pesquisadores, como CAMOENs e.t alii (1976) em Porto Rico, e McDOWELL et alii (1976a), no México, não observaram efeito significativo da idade ou ordem de parição na duração da láctação em rebanhos de vacas holandesas.

A duração da lactação aumenta com a idade da vaca, na razão de 0,2393 dias por mês de idade, equivalendo a um aumento de 2,87 dias para cada 12 meses a mais de idade. 


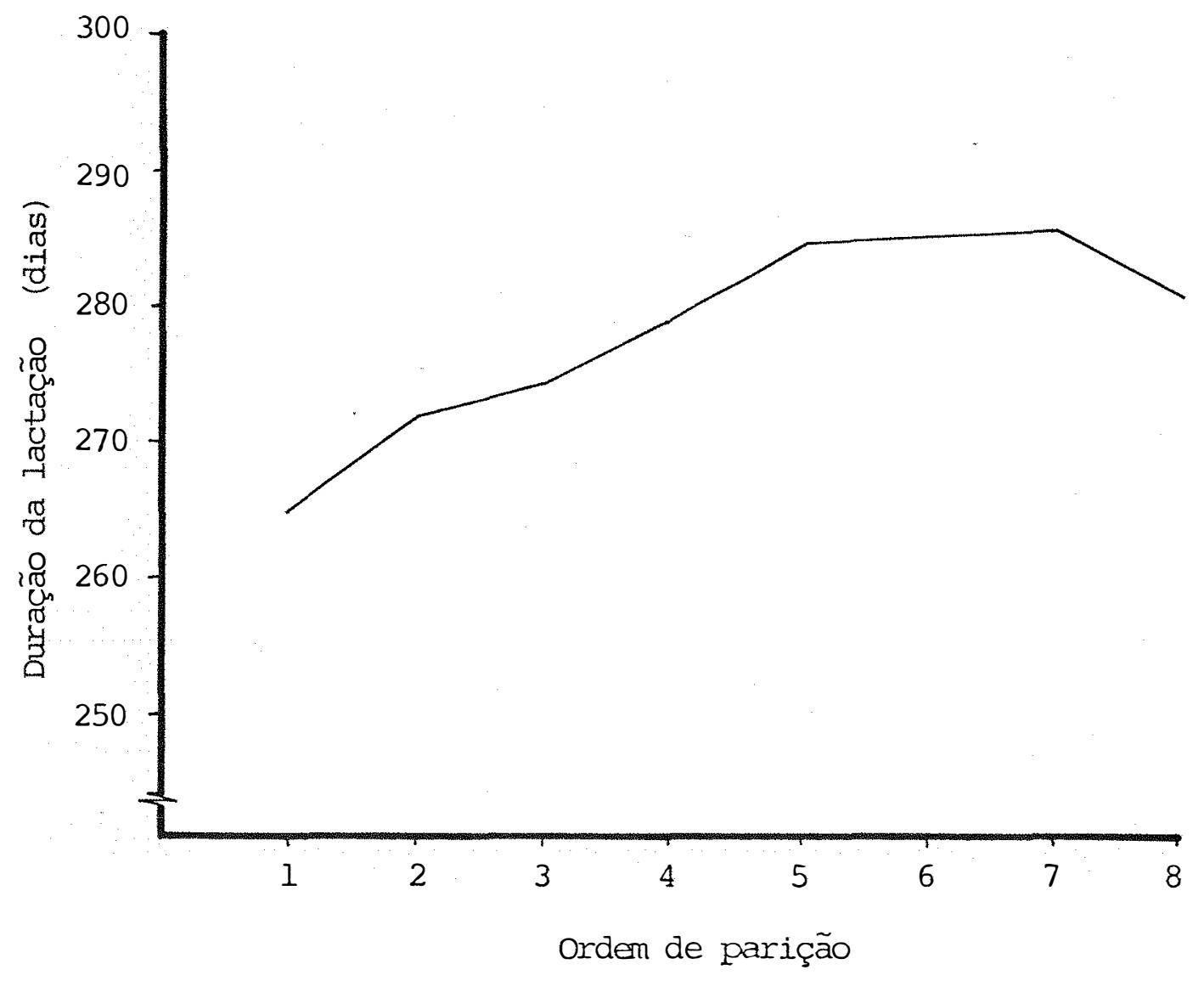

Figura 6 - Duração média da lactação segundo a ordem de parição 
Tabela 8 - Duração média da lactação, erro da média e número de observações de acordo com a ordem de lactação

\begin{tabular}{ccc}
\hline Ordem de lactação & $\begin{array}{c}\text { Número de } \\
\text { observações }\end{array}$ & $\begin{array}{c}\text { Duração da lactação } \\
\pm \text { erro da média }\end{array}$ \\
\hline $1^{a}$ & 407 & $265,48 \pm 4,30$ \\
$2^{a}$ & 304 & $272,03 \pm 4,92$ \\
$3^{a} \cdot$ & 237 & $274,50 \pm 5,57$ \\
$4^{a} \cdot$ & 183 & $277,43 \pm 6,34$ \\
$5^{a}$ & 131 & $284,28 \pm 7,44$ \\
$6^{a}$ & 99 & $285,94 \pm 8,61$ \\
$7^{a}$ & 74 & $286,43 \pm 9,87$ \\
$8^{a}$ & 94 & $281,32 \pm 9,30$ \\
\hline
\end{tabular}

Grupo genētico

O grupo genético das vacas apresentou efeito altamente significativo $(P<0,01)$ sobre a duração da lactạ ção. Os componentes ortogonais linear, quadrático e cúbico foram significativos, sendo que o termo linear apresentou maior importância, pois explica 67,83\% da soma dos quadrados do grau de sangue (Tabela 5 do Apêndice).

Na Tabela 9 e na Figura 7 estão apresentadas as médias da duração da lactação de acordo com o grupo genético das vacas. 
Tabela 9 - Duração média da lactação, erro da média e nū mero de observações segundo o grupo genético das vacas

\begin{tabular}{lcc}
\hline Grupo genético & $\begin{array}{c}\text { Número de } \\
\text { observações }\end{array}$ & $\begin{array}{c}\text { Duração da lactação } \\
\pm \text { erro da média** }\end{array}$ \\
\hline $1 / 2 \mathrm{H}: 1 / 2 \mathrm{GU}$ & 155 & $218,92 \pm 6,83 \mathrm{a}$ \\
$3 / 4 \mathrm{H}: 1 / 4 \mathrm{GU}$ & 356 & $275,94 \pm 4,52 \mathrm{~b}$ \\
$7 / 8 \mathrm{H}: 1 / 8 \mathrm{GU}$ & 455 & $282,95 \pm 4,15 \mathrm{~b}$ \\
$15 / 16 \mathrm{H}: 1 / 16 \mathrm{GU}$ & 281 & $284,77 \pm 5,35 \mathrm{~b}$ \\
$31 / 32 \mathrm{H}: 1 / 32 \mathrm{GU}$ & 282 & $309,06 \pm 5,43 \mathrm{bc}$ \\
\hline
\end{tabular}

* $\quad \mathrm{H}=$ Holandês

$\mathrm{GU}=$ Guzerà

* Médias seguidas de letras iguais não diferem entre si pelo Teste de Tukey aproximado.

Observa-se um aumento da duração da lactação das vacas à medida que aumenta a contribuição dos genes da raça Holandesa, especializada na produção de leite. Considẹ rando que a duração da lactação é um componente fundamental da produção de leite por lactação, evidencia-se através destes resultados o sucesso do programa de cruzamento absor vente, empregado no rebanho sob estudo.

Esta tendência concorda com os resultados re latados por BRANDT et alii (1966) e BRANTON et alii (1967) 


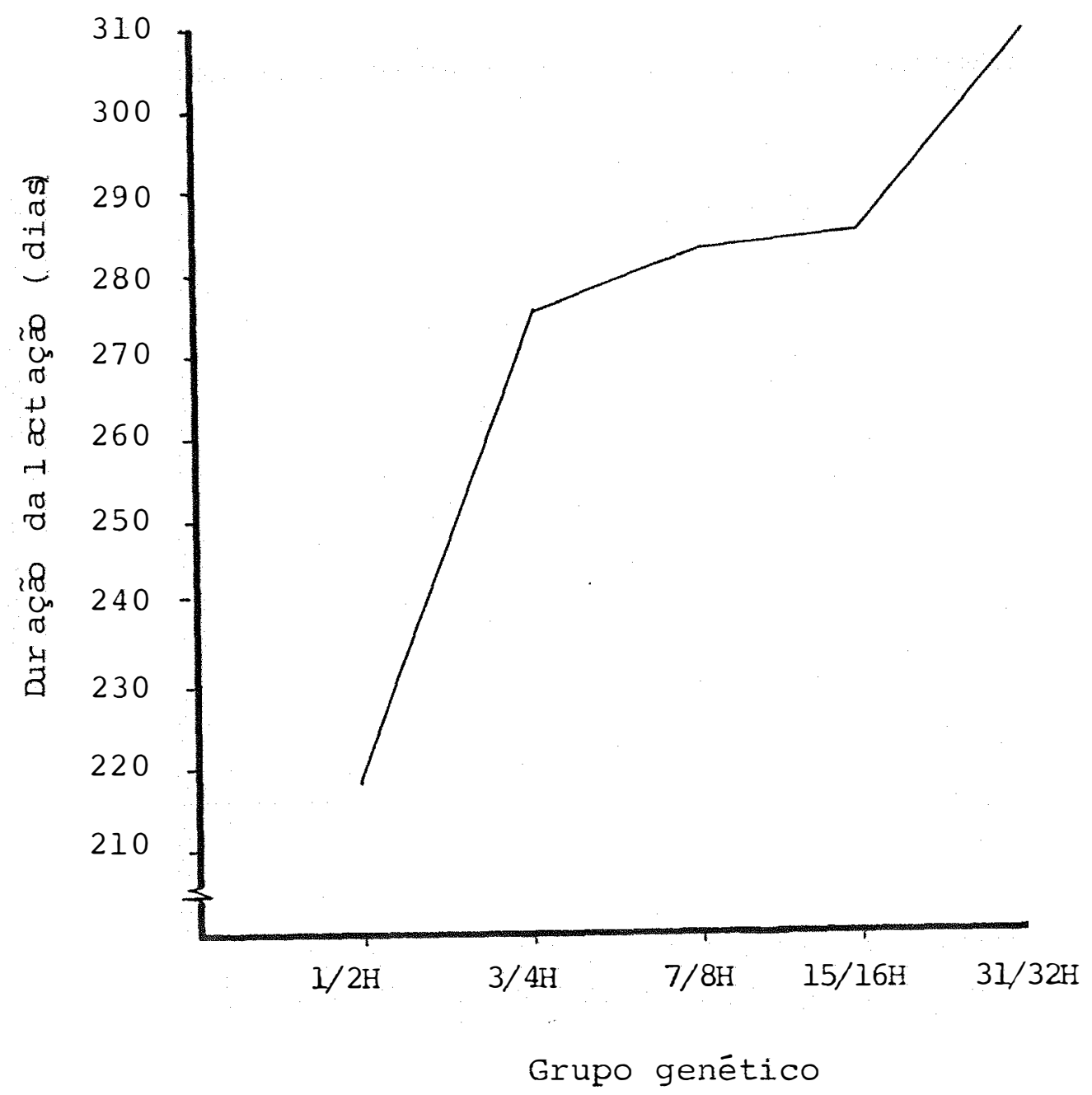

Figura 7 - Duração média da lactação de acordo com o grupo genético das vacas 
nos Estados Unidos, bem como com os publicados por ALVES NETO (1967) no Brasil, ao contrário dos resultados obtidos por KASSIR (1969), MANDUJANO (1979), RIBAS (1981), MADALENA et alii (1983) e NOBRE (1983) que, em geral,não observaram efeito significativo dos diferentes grupos genéticos.

Estes resultados, aparentemente contraditórios,podem ser explicados pelas informações obtidas por MADALENA et alii (1982), as quais mostraram a existência da interação significativa entre grupo genético e nível de tecnologia do sistema de produção. De fato, as diferenças entre estes grupos dependem do sistema de produção emprega do. Quando o sistema pode ser caracterizado como de alto nỉvel tecnológico a tendência observada é no sentido de aú mentar a duração da lactação com o aumento da contribuição da raça especializada.

Em vista destes argumentos pode-se inferir que o nível. de manejo e alimentação empregado na Fazenda Pinhalzinho é suficiente para evidenciar as diferenças entre os grupos genéticos existentes no rebanho.

4.3. Produção de leite ajustada para duração da lactação

Os resultados da análise da variância da produção de leite, ajustada por covariância para a duração média de lactação são apresentados na Tabela 7 do Apêndice, 
enquanto que as Tabelas 8,9 e 10 do Apêndice apresentam as médias de produção de leite de acordo com o ano de parição, época de parição e grupo genētico, respectivamente.

Conforme pode ser observado na Tabela 7 do Apêndice a duração da lactação exerceu efeitos linear e quadrātico altamente significtivos sobre a produção de leite. O coeficiente de correlação linear entre duração da lac tação e produção de leite foi 0,699. Este valor implica que uma fração importante da variação, na produção de leite por lactação, pode ser atribuido às diferenças observadas na duração da lactação. De fato, a duração da lactação como covariável no modelo determinou uma grande redução no qua drado médio residual da produção de leite, como pode. . ser comparado nas Tabelas 4 e 7 do Apêndice.

A Figura 8 ilustra a curva de resposta da produção de leite em relação à duração da lactação. A Tabela 11 do Apêndice apresenta a produção de leite estimada em função da duração da lactação e os respectivos fatores de correção. Em consequência deste grande efeito da duração da lactação sobre a produção de leite, as médias de produção ajustadas mostradas nas Tabelas 8,9 e 10 do Apêndice diferem bastante daquelas apresentadas nas Tabelas 2,3 e 5 . Particularmente importantes são as diferenças entre produção de leite ajustada e não ajustada para a duração da lactação, conforme o grupo genético (Tabelas 10 do Apêndice e 5 e Figuras 9 e 3, respectivamente). 


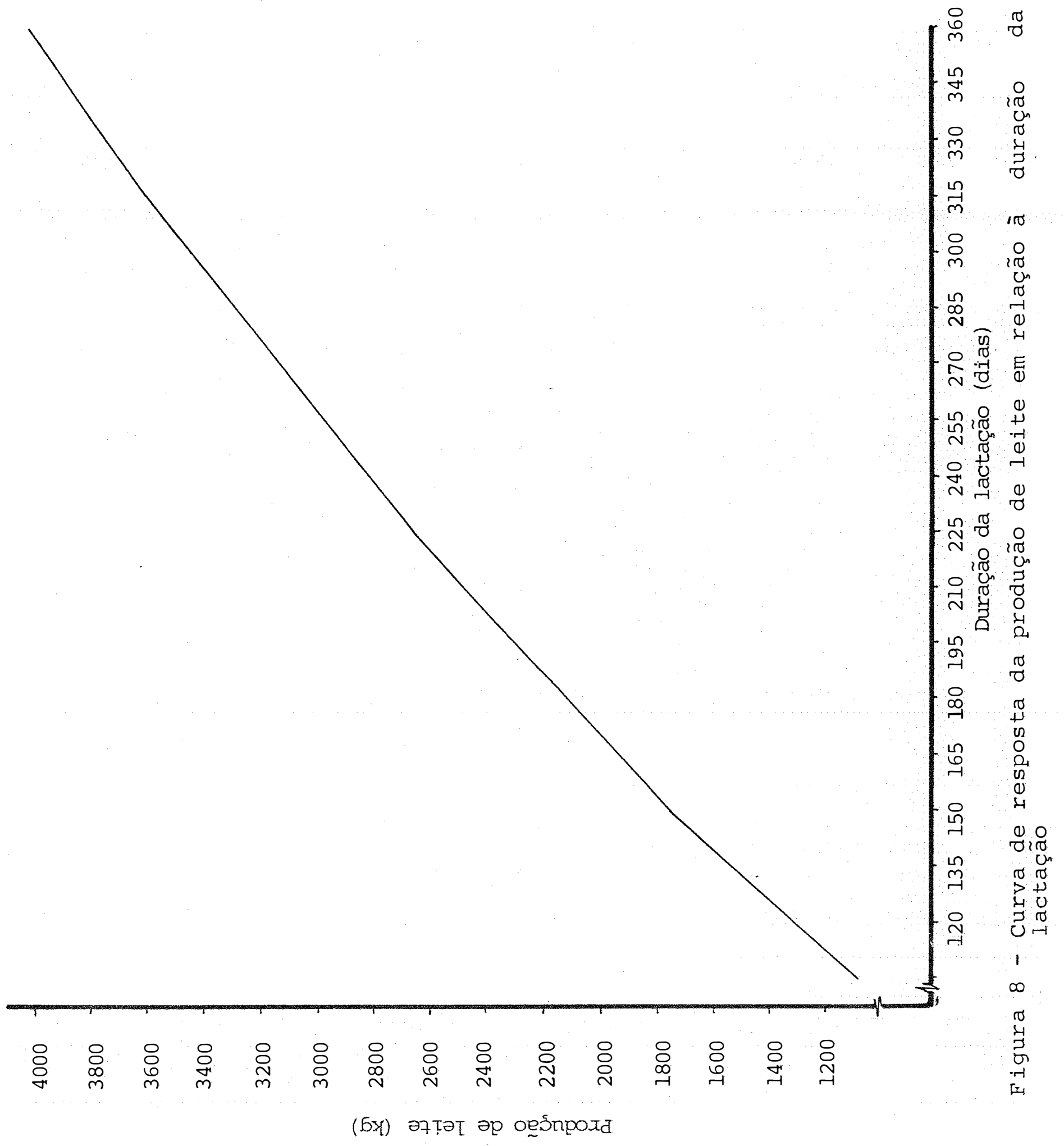




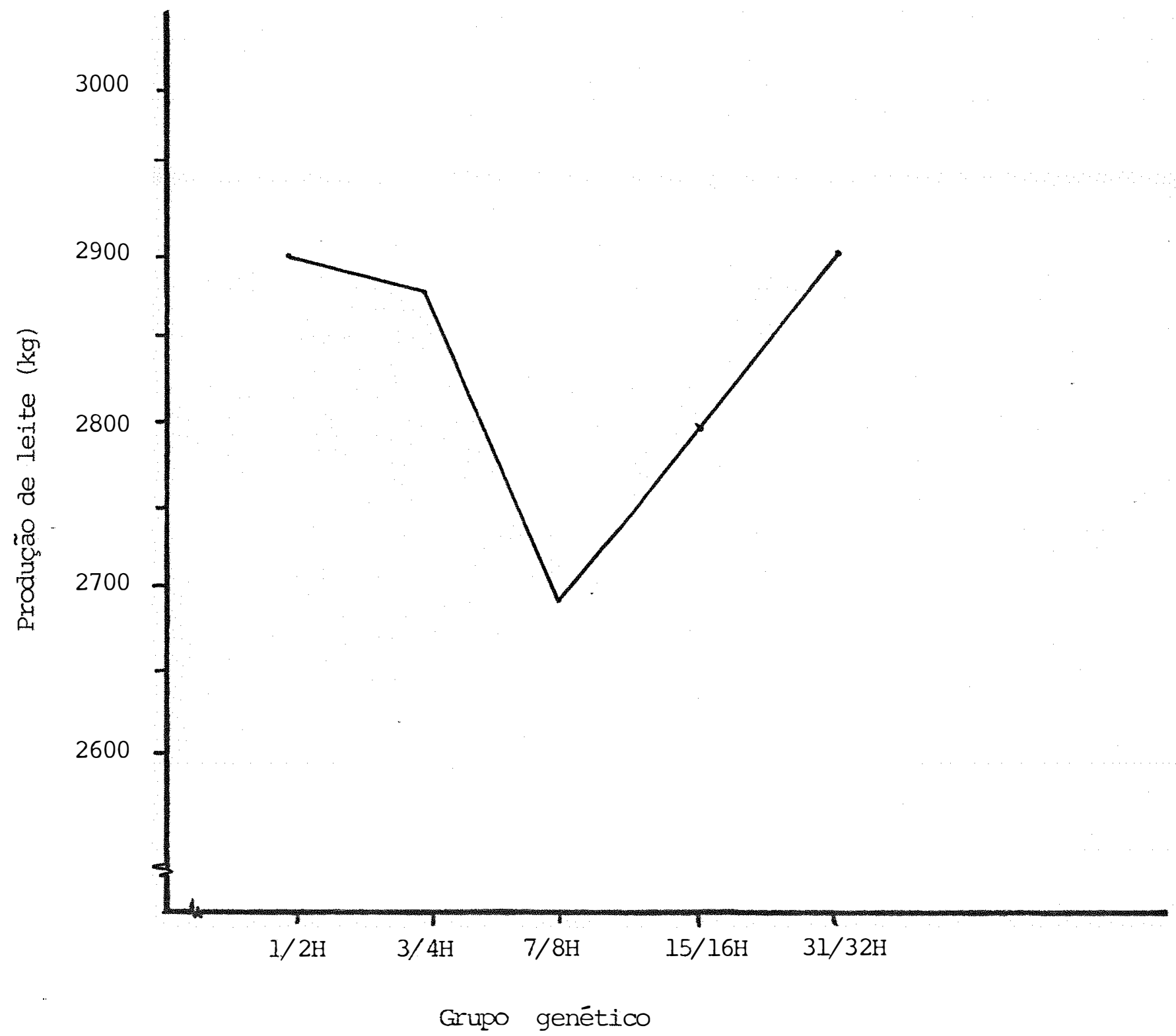

Figura 9 - Média de produção de leite ajustada para duração da lactação de acordo com o grupo genético das vacas 
O ajuste por covariāncia para a duração média de lactação ( 273 dias) distorce completamente as comparações entre os diferentes grupos genéticos. Através do mecanismo deste ajuste, a produção de leite das vacas $1 / 2 \mathrm{H}$ : 1/2GU, que apresentam duração de lactação menor, conforme Tabela 5 é elevado artificialmente de 2.254,5 para 2.906,84 $\mathrm{kg}$ ao mesmo tempo que as vacas $31 / 32 \mathrm{H}: 1 / 32 \mathrm{GU}$ de maior perío do de lactação, têm a sua produção diminuída de 3.309,26 pa ra $2.899,90 \mathrm{~kg}$ (Tabela 10 do Apêndice).

Considerando que as diferenças na duração da lactação dos vários grupos genéticos é. de natureza genética, como conseqưencia deste ajuste, ocorre uma remoção da varia bilidade genética entre os mesmos, distorcendo a comparação e a análise do próprio programa de cruzamento.

Do mesmo modo que este ajuste afeta as comparações entre grupos genéticos, também são afetadas as médias de acordo com o ano de parição e com a época de parí ção mostrados nas Tabelas 8 e 9 ão Apêndice, no caso do ano ilustrado na Figura 10.

Conforme a Tabela 6 a duração da lactação variou com os diferentes anos, devido à causas genéticas (diferenças nos grupos genéticos em cada ano) e ambientais. o ajuste da produção de leite para a duração da lactação, determina mudanças para mais ou para menos das médias, de- 


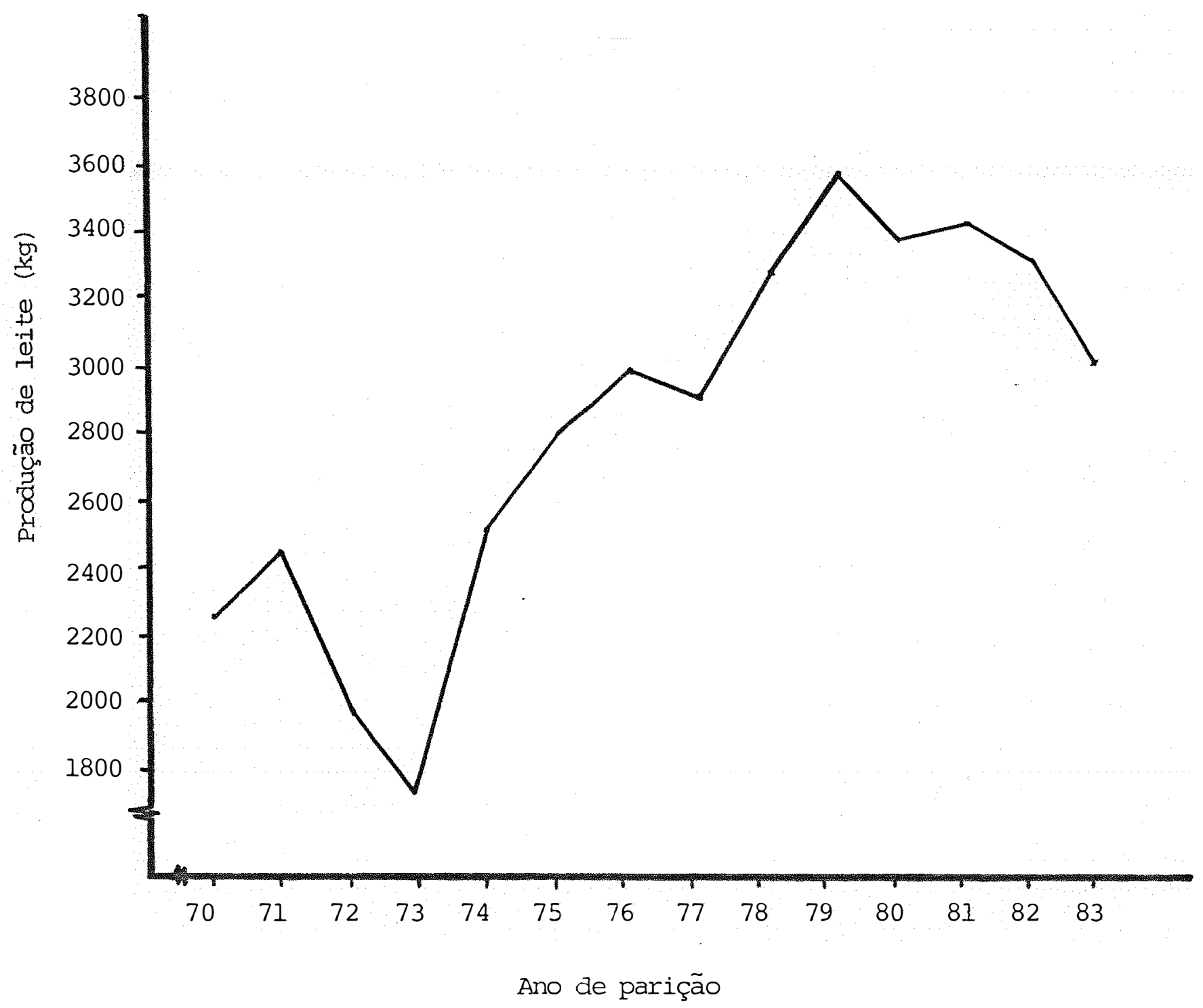

Figura 10 - Média de produção de leite ajustada para duração da lactação de acordo com o ano de parição 
pendendo da duração média da. lactação em cada ano.

Tendo em vista que na literatura consultada, não foi possível constatar nenhuma referência a esta situação, es es resultados foram apresentados para caracterizar os eventuais problemas que possam ocorrer com o ajustamento da produção de leite para a duração da lactação e ao mesmo tempo justificar a razão de se estudar separadamen te, a produção de leite por lactação e a duração da mes ma.

4.4. Estimativas da herdabilidade

Os resultados da anālise da variāncia, de acordo com o modelo 3 que inclui o efeito aleatório de tourorestão apresentados nas Tabelas 12, 13 e 14 do Apêndice, para produção de leite, duração da lactação e produção de leite ajustada para duração da lactação, respectivamente. Tais análises foram efetuadas em um conjunto de 1.374 lacta ções, incluindo apenas os 24 touros com mais de cinco fiIhas.

As estimativas da herdabilidade e os respectivos erros para produção de leite, duração da lactação e produção de leite ajustada para duração da lactação foram $0,184 \pm 0,068,0,178 \pm 0,067$ e $0,084 \pm 0,044$, respectivamen te. 
As estimativas obtidas para a produção de leite ajustada ou não estão, no geral, abaixo das encontradas pela maioria dos pesquisadores conforme mostrado na Tabela 1. Uma das razões, para esta ocorrência consiste no empre go de modelo estatístico relativamente simples, pois não inclui todos os efeitos, em particular, o efeito aleatório de vacas. Deste modo' o quadrado médio do resíduo pode superestimar a variância residual, afetando a estimativa da herdabilidade.

Outra possível causa seria o fato de grande variância fenotípica expressa por alto coeficiente de variação que pode ter determinado um maior quadrado médio do resíduo.

Por outro lado, o ajuste da produção de leite para a duração da lactação, provavelmente, determinou uma redução das diferenças entre touros, com filhas de diferentes grupos genéticos, fazendo o componente de variância entre touros menor e conseqüentemente a própria estimativa da $h^{2}$ da produção de leite corrigida passasse para 0,084. 
5. CONCLUSÕES

A anālise estatística e genética dos registros de produção de leite e duração da lactação do rebanho considerado permitiu estabelecer as seguintes conclusões:

1. O ano de parição exerceu efeitos significativos sobre a produção de leite e duração da lactação. Houve uma tendência positiva evidenciando mudanças genéticas e ambientais no sentido desejado.

2. Não foi observado efeito da época de pari ção sobre a produção de leite e duração da lactação, resultado este que evidencia condiçc̃es adequadas de alimentação nas vārias épocas do ano.

3. O grupo genético das vacas exerceu efeito importante sobre a produção de leite e duração da lactação, de tal modo que as vacas 1/2 Holandês: 1/2 Guzerá foram infe- 
riores, enquanto que não houve diferenças entre os grupos 3/4 Holandês: 1/4 Guzerá, 7/8 Holandês:1/8 Guzerá e 15/16 Hol andês:l/16 Guzerá. O grupo 31/32 Holandês:1/32 Guzerá foi superior em termos de produção de leite e maior período de lactação. Tais resultados evidenciam um sistema de produção adequado à expressão do potencial genético das raças com mais proporção de genes de raça Holandesa. Nest as condições é válido o programa de cruzamento absorvente, dirigido para a especialização do rebanho.

4. O uso da produção de leite por lactação corrigida para a duração média da lactação acarretou uma remoção da variabilidade entre os diferentes grupos genéticos, distorcendo as comparações entre os mesmos.

5. As estimativas da herdabilidade da produção de leite e duração da lactação foram consideradas baixas com valores da ordem de 0,184 $\pm 0,068$ e 0,178 $\pm 0,067$, respectivamente. 
6. LITERATURA CITADA

ALVES NETO, F.; I. FANG; J.D. MELO TELLES, W.M.G. FONZARI; O.R. KVARNSTROMO. 1967. Comportamento médio das vacas e rebanhos controlados pelo Serviço de Controle Leiteiro da Associação Brasileira de Criadores de Bovinos. 1945-1966. Revista dos Criadores, São Paulo, 38:18108.

BLANCHARD, R.P.; A.E. FREEMAN E P.W. SPIKE. 1966. Variation in lactation yield of milk constituents. J. Dairy Sci., Champaign, 49: 953-956.

BRANDT, G.W.; C.C. BRANNON; W.R. HARVEY e R.E. MCDOWELL. 1966. Effects of crossbreeding on production traits in dairy cattle. J. Dairy Sci., Champaign, 49:12491253. 
BRANTON, C.; R.E. MCDOWELL e M.A. BROWN. 1967. Cruzamento zebu-europeu como base de melhoramento de gado leiteiro nos E.U.A. Zootecnia, São Paulo, 5:21-59.

BRANTON, M.A. E D.L. EVANS. 1972. Interrelationship among months and seasons of calving, feeding regimes milk and fat yield and lactation in a Louisiana Holstein herd. I. Dairy Sci., Champaign, 55:395-402.

BRANTON, C.; G. RIOS; D.L. EVANS; B.R. FARTHING e K.L.KOONCE. 1974. Genotype-climatic and other interaction effects for productive responses in Holstein. J. Dairy Sci., Champaign, $57: 833-41$.

BROWN, M.A.; T.C. CARTWRIGHT e A.W. OURSHI. 1960. Influence of season of freshening on the milk yield and butterfat percentage of Holstein Friesian and Jersey cows in Texas. J. Dairy Sci., Champaign, 43:88 (Abstract).

CAMOENS, J.K.; R.E. MCDOWELL; L.D. VAN VLECK e J.D. RIVERA ANAYA. 1976. Holsteins in Puerto Rico: I. Influence of herd, year, age and season on performance. J. Agri. Uni. Puerto Rico, Rio Piedras, 60:526-539.

CARNEIRO, G.G. 1953. Testing dairy bulls under the penkeeping system in Brazil. J. Dairy Sci., Champaign, 36:57-63. 
COSTA, L.Z.; J. LOPEZ; W.M. OLIVEIRA E A.C.P. MACHADO. 1976. Seasonal lactation curves in Holstein-Friesian, Jersey and Ayrshire cows. Animal Breeding Abstracts, 44:293.

COSTA, C.N. 1980. Fatores genéticos e de meio na produção de leite e eficiência reprodutiva de um rebanho Holandês. Universidade Federal de Viçosa. Viçosa, MG. 93p (Tese de Mestrado).

DIAS, F.M.; S.C.P. BARRETOS; O.P. SANTANA; T.FARIA; P.E.S. ARAŨJO. 1974. Variações na produção de leite do rebanho Holandês da Estação Experimental de são Bento do Una, Pernambuco. In: Reunião Anual da Sociedade Brasileira de Zootecnia. $11^{\mathrm{a}}$, Fortaleza, CE. p.84-85.

ERB, R.E. 1960. Relationship between body weight on yield of dairy cow. J. Dairy Sci., Champaign, $\underline{44}(6): 872$.

FARTHING, B.R. e J.E. LEGATES. 1957. Genetic covariation between milk yield and fat percentage in dairy cattle. . J. Dairy Sci., Champaign, 40(5):639-646.

FERREIRA, G.S. 1983. Estudo de fatores genéticos e de ambiente na produção de leite e em caracteristicas reprodutivas de um rebanho holandês. Universidade Federal de Viçosa, Viçosa, MG. 14lp. (Tese de Mestrado). 
FREITAS, M.A.R.; F. NAUFEL; V.L. CARDOSO e E.B. OLIVEIRA. 1980. Aspectos do desempenho reprodutivo de vacas da raça Holandesa preta e branca em são Paulo. In: Reunião Anual da Sociedade Brasileira de Zootecnia. 17a., Fortaleza,CE. 1980. Anais, p. 180.

FREITAS, M.A.R. 1981. Aspectos fenotípicos e genéticos da produção de leite e suas relações com a reprodução de um rebanho da raça Holandesa. Faculdade de Medicina de Ribeirão Preto. Ribeirão Preto, 146p. (Tese de Doutorado) .

GACULA Jr., M.C.; S.N. GAUNT e R.A. DAMON Jr. 1965. Estimates of age effect on milk composition. J. Dairy Sci., Champaign; 48:803 (Abstract).

GACULA Jr., M.C.; S.N. GAUNT e R.A. DAMON Jr. 1968. Genetic and environmental parameters of milk constituints for five breeds. I. Effect of herd, year, season and age of the cow. I. Dairy Sci., Champaign, 51:428-437.

GAMES, H.; H.R. PONCE e J.M. BERRUECOS. 1972. Estimacion de parametros genéticos hato de ganado Holstein estabulado en clima subtropical. Tec. Pec., México, 20:45-51.

GOIC, M.L. 1974. Características de la curva de lactancia con respecto a la época ảe parición en la zona de Osorno. Agricultura técnica, Santiago, 34:94-97. 
HARDIE, A.R.; E.L. JENSEN e W.J. TYLER. 1978. Genetic and economic implications of single trait selection for protein and solids-not-fat. $\underline{J}$. Dairy Sci., Champaign, $61(1): 96-101$.

HARVEY, W.R. 1972. Instructions for use of least squares and maximum likehood general purpose program. The Ohio state University. Mimeo. 23p.

HARVEY, W.R. 1979. Least-squares analysis of data with unequal subclass numbers. USDA/ARS. $157 \mathrm{p}$.

HICKMAN, C.G. e C.R. HENDERSON. 1955. Components of the relationship between level of production and rate of maturits in dairy cattle. J. Dairy Sci., Champaign, $\underline{38}$ : 883-890.

HOOVEN Jr., N.W.; R.H. MILLER e R.D. PLOWNMAN. 1968. Genetic and environmental relationship among efficiency, yield, consuption and. weight of holdstein cows. J. Dairy Sci. Champaign, 51:1409-1419.

JARA, A.M. e J.M. WHITE. 1972. Factores climáticos y producción de leche en la costa Central del Perú. Mem. Ass. Lat. Ame. Prod. Anim., México, 7: 89-104.

JOHANSSON, J. 1961. Genetic aspects of dairy cattle breeding Ed. Oliver e Boyd, London. 261 . 
JOHANSSON, J. e J. HENDEL. 1972. Genética y mejora animal. Trad. por F.P. MAS e P.D. MALUENDA. Ed. Acribia, Zaragoza. $567 \mathrm{p}$

KASSIR, S.A.; K.H. JUMA; E F.H. AL-JAFF. 1969. A further study on dairy characters in Friesian on crossbreed cattle in Iraque. Trop. Agriculture, Trinidad, 46:359363.

KATPATAL, B.G. 1982. Raças e cruzamentos para a produção de bovino leiteiro nos trópicos: resultados experimentais. In: Anais do lo Simpósio Brasileiro de Melhoramento Genético de Bovino Leiteiro nos Trópicas. Campus U.F.J.F. Juiz de Fora - MG. p.193-267.

KIWUNA, G.H. 1974. Age, year and season effects on dairy performance of Friesian and Jersey cattle on privalety owned farms in Kenia. East Afr. Agric. for J., Kenia, $39(3): 298-306$.

LEE, A.J. 1974. Month, year, herd effects on age adjustment on first lactation milk yield. J. Dairy Sci., Champaign $57(3): 332-338$

LOBO, R.B. E F.A.M. DUARTE. 1977. Desempenho produtivo da raça Pitangueiras (5/8 Red Poll x 3/8 Zebu) e de cruzamentos Red Poll x Zebu no trópico brasileiro. Rev. Fac. Med. Vet. e Zootec. USP, São Paulo, SP. 14:315. 
LOBO, R.B. 1980 Métodos de avaliação de parâmetros fenotípicos e genéticos em bovinos da raça Pitangueiras. Fac. Med. Vet. Zootec. USP São Paulo, SP. 179p. (Tese de Doutọ rado) .

LOGANATHAN, S. e N.R. THOMPSON. 1968. Composition of cows milk. I. Environmental and managerial influences. I. Dairy Sci., Chapaign, 51(12):1928-1932.

LUSH, J.L. 1949. Heritability of quantitative characters in farm animals. Proc. 8th. Int. Congr. of Genet. Suppl. Hereditás, Sweden, 356-374.

LUSH, J.L. e R.R. SHRODE. 1950. Changes in milk production with age and miling frequency. J. Dairy Sci., Champaign, $\underline{33}(5): 338-357$.

LYN, C.Y. e F.R. ALLAIRE. 1978. Efficiency on selection on milk yield to a fixed age. J. Dairy Sci., Champaign, 61: 489-496.

MADALENA, F.E.; FREITAS, A.F. e M.L. MARTINEZ. 1980. Evaluación comparativa de la producción de leche en vacas Holandesas y mestizas Holandes:Gir. In. Conf. Mundial Prod. Anim. 4. Buenos Aires, 1980. Memorias. Buenos Aires, AAPA, p. 650658 . 
MADALENA, F.E.; R.L. TEODORO; A.M. LEMOS e R.T. BARBOSA. 1982. Estratégias de cruzamentos entre raças leiteiras na região sudeste. In: Anais do lo Simpósio Brasileiro de Melhoramento Genético de Bovino Leiteiro nos Trópicos. Campus da U.F.J.F. Juiz de Fora, MG. p.43-69.

MADALENA, F.E.; J. VALENTE; R.L. TEODORO e J.B.N. MONTEIRO. 1983. Produção de leite e intervalo entre partos de vacas HPB e Mestiças HPB x Gir num alto nível de manejo. Pesg. Agropec. Bras., Brasilia, DF., 18(2):195-200.

MAHADEVAN, P. 1956. Variation in performance of european dairy cattle in Ceilon. J. Agric. Sci., Cambridge, 42 : $164-170$.

MAIJALA, K. e M. HANNA. 1974. Reliable phenotypic and genetic parameters in dairy cattle. In: Proceedings. I Congreso Mundial de Genetica Aplicada a la Produccion ganadera. Madrid. p.541-564. Vol. I.

MANDUJANO, M.J. 1979. Alguns fatores genéticos e ambientais como causa de variação da produção de leite e do período de lactação. Esc. Vet. U.F.M.G., Belo Horizonte, MG. 64p. (Tese de Mestrado).

MCDOWELL, R.E. 1972. Improvement of livestock production in warm climates. Ed. Freeman and Company. San Francisco, $588 \mathrm{p}$. 
MCDOWELL, R.R.; J.K. CAMOENS; L.D. VAN VLECK; E. CHRISTENSEN e E. CABELLO FRIAS. 1975. Factors affecting performance of Holsteins in Mexico. J. Dairy Sci., Champaign, 58 (5): 755.

MCDOWELL, R.E.; J.K. CAMOENS; L.D. VAN VLECK; E. CHRISTENSEN e E.CABELLO FRIAS. 1976a. Factors affecting performance of Holsteins in subtropical regions of Mexico. J. Dairy Sci., Champaign, 59(4):722-729.

MCDOWELL, R.E.; N.W. HOOVEN e J.K. CAMOENS. 1976b. Effect of climate on performance of holsteins in first lactation. J. Dairy Sci., Champaign, 59(5):965-973.

MEJIA, N.A. 1981. Fatores genéticos e de meio no desempenho de bovinos das raças Suiça Parda e Holandesa, na República de Honduras, América Central. Univ. Fed. Viçosa, Viçosa, MG. 78p (Tese de Mestrado).

MILLER, P.D. e C.R. HENDERSON. 1968. Seasonal age correction factors by maximum likelihood. J. Dairy Sci., Champaign, 51: $955-963$

MILLER, R.H. e N.W. HOODVEN Jr. 1969. Factors affecting whole and part lactation milk yield and fat percentage in herd of holstein cattle. J. Dairy Sci., Champaign, 52:1588-600. 
MILLER,' P.D.; W.E. LENTZ E C.R. HENDERSON. 1970. Joint influency of month and age of calving on milk yield of Holstein cows in Northeastern United States. J. Dairy Sci., Champaign, 53: $351-357$.

NAUFEL, F. 1965/1966. Efeitos de alguns fatores ambientais e genéticos na produção de leite e gordura do rebanho experimental Holandès preto e branco do Departamento de Produção Animal de são Paulo. Bul. Industr. Anim., São Paulo, 23 (no único) : 21-54.

NEIVA, R.S. 1977. Efeito de alguns fatores de meio sobre a produção de leite de um rebanho Holandês preto e branco. Esc. Vet. U.F.M.G., Belo Horizonte, MG. 9lp (Tese de Mestrado)

NEIVA, R.S.; H.M. e I.B.M. SAMPAIO. 1979. Alguns fatores de meio influenciando a produção de leite, em um rebanho Holandês, no sul do Estado de Minas Gerais. Arg. Esc. Vet. U.F.M.G., Belo Horizonte, MG, 31 (2):263-273.

NOBRE, P.R.C. 1983. Fatores genéticos e de meio em caracteristicas produtivas e reprodutivas do rebanho leiteiro da Universidade Federal de Viçosa, Estado de Minas Gerais. Univ. Fed. Viçosa, Viçosa, MG., 128p (Tese de Mestrado). 
NORMAN, H.D.; P.D. MILLER; B.T. MCDANIEL; F.N. DICKINSON e E.R. HENDERSON. 1974. Factors for standardizing lactation records for age and month of calving. USDA. D.H.I.A., Bull ARS - NE - 40. 9lp.

OLIVEIRA, F.M. 1973. Alguns fatores que afetam a produção de leite e um rebanho Holandês preto e branco. Esc. Vet. U.F.M.G., Belo Horizonte, MG. (Tese de Mestrado).

PEIXOTO, A.M. 1965. Estudo sobre alguns aspectos do crescimento, eficiência reprodutiva e produção de leite dos mestiços da raça Guernsey em Piracicaba. ESALQ, Piracicaba,SP. l1lp. (Tese de Cātedra).

PEREIRA, J.C.C. 1983. Melhoramento genético aplicado aos animais domésticos. Esc. de Vet. da UFMG. Belo Horizonte, MG. $430 \mathrm{p}$

PRIMO, G.B.; E.C. BARRETO CAMPELO; H.C.MANSO; A.N. COSTA e J.W.B. CRUZ. 1980. Desempenho produtivo de Holandês, variedade preto e branco, puro por cruzamento, explorado no sertão do Estado de Pernambuco. In: Congresso Brasileiro de Zootecnia, Fortaleza, CE. Anais do I Congresso Brasileiro de Zootecnia.

REIS, S.R. 1977. Fatores de variação do período de lactação e da produção de leite num rebanho Mestiço Europeu-Zebu. Esc. Vet. UFMG. Belo Horizonte, MG. 86p (Tese de Mestrado). 
RIBAS, N.P. 1981. Fatores de meio e genéticos em características produtivas e reprodutivas de rebanhos holandeses da Bacia Leiteira de Castrolanda, Estado do Paraná. Univ. Fed. de Viçosa. Viçosa, MG. 14lp. (Tese de Mestrado).

RIOS, G. e C. BRANTON. 1973. Effects of climate on milk production and estimates of genotype-climatic environmental interactions. J. Dairy Sci., Champaign, 56:662. (Abstract).

RIVERos, M.A.A. 1979. Causas de variação e covariação da produção de leite. Esc. Vet. UFMG, Belo Horizonte, MG., 42p. (Tese de Mestrado).

SABUGOSA, I.M. e R.M. MIRANDA. 1963. Variação da produção de leite e influência da época de parição no sistema de retiros. Agronomia, Univ. Rural Km 47-Rio de Janeiro, 21:2137.

SARGENT, F.D.; K.R. BUTCHER e J.E. LEGATES. 1967. Environmental influence on milk constituints. J. Dairy Sci., Champaign, 50: $177-184$.

SCHAEFFER, L.R. e C.R. HENDERSON, 1972. Effects of days dry and days open on holstein milk production. I. Dairy Sci. Champaign, 55(1):107-112.

SCHMIDT, G.H. e L.D. VAN VLECK. 1974. Principles of dairy science. Ed. Freeman and Company. San Francisco. 588p. 
SIQUEIRA, A.C.M.F. 1979. Fatorss de variação da produção de leite e gordura de vacas da raça Holandesa, variedade malhada de preto. Instituto de Biociências, USP. São Paulo, SP. 72p. (Tese de Doutoradol.

SPECHT, L.W. e L.D. MCGILLIARD. 1960. Rates of improvement by progeny testing in dairy herds of various sizes. J. Dairy Sci., Champaign, 43:63-75.

TUCKER, H.A. 1979. Mammary physiology. Bulletin Dry - P5L444. Michigan State University Printing Office. East Lousing. Michigan, 189p.

VALLE, A. 1977. Desempenho produtivo de um rebanho de vacas holandesas. Fac. Med. Ribeirão Preto, USP. Ribeirão Preto, SP. 116p. (Tese de Mestrado).

VALLE, A. e L.H. NALI. 1978. Cinco lactações consecutivas em vacas holandesas numa região tropical úmida do Brasil. Ciência e Cultura, são Paulo, SP. 30:201-207.

VAN VLECK, L.D. e C.R. HENDERSON. 1961. Measurement of genetic trend. J. Dairy Sci., Champaign, $\underline{44}(9): 1328$.

VENCOVSKY, R.; U.J. DIAS e Y. RICARDO. 1970. Um modelo genētico aplicado à análise de dados de produção de leite em gado bovino. Relatório. Departamento de Genética da ESALQ. Piracicaba, SP., p.130-136. 
VERDE, O.; C.J. WILCOX; M. KOGER; D. PLASSE e F.G. MARTIN. 1972. Influências genēticas, ambientais y sus interaciones sobre la producción lechera en Venezuela. Mem. Ass. Lat. Prod. Anim., México, 7:117-135.

WARWICK, E.J. e J.E. LEGATES. 1979. Breeding and improvement of farm animals. VII Ed. Tata McGrew Hill Publishing Co. Ltd. , New Delhi. 326p.

WEBB, D.W. 1977. Factors or standardizing lactation records. Dairy in formation sheet. Gainesville, University of Florida, Cooperative Extension Service.

WIGGANS, G.R. e L.D. VAN VLECK. 1979. Extending partial lactation milk and fat records with a function of lastsample production. J. Dairy Sci., Champaign, 62(2):316-325.

WILSON, P.N. e T.R. HOUGHTON. 1962. The developmental on the herd of Holstein-Zebu cattle at the Imperial college of Tropical agriculture. Trinidad. Emp. J. Exp. Agric. Oxford, $30(118): 159-180$.

WUNDER, W.W. e L.D. MCGILLIARD. 1964. Heritabilities and genetic correlation for components of milk in Holstein and Guernsey, I. Dairy Sci., Champaign, 47:700 (Abstract). 
APENDICE 


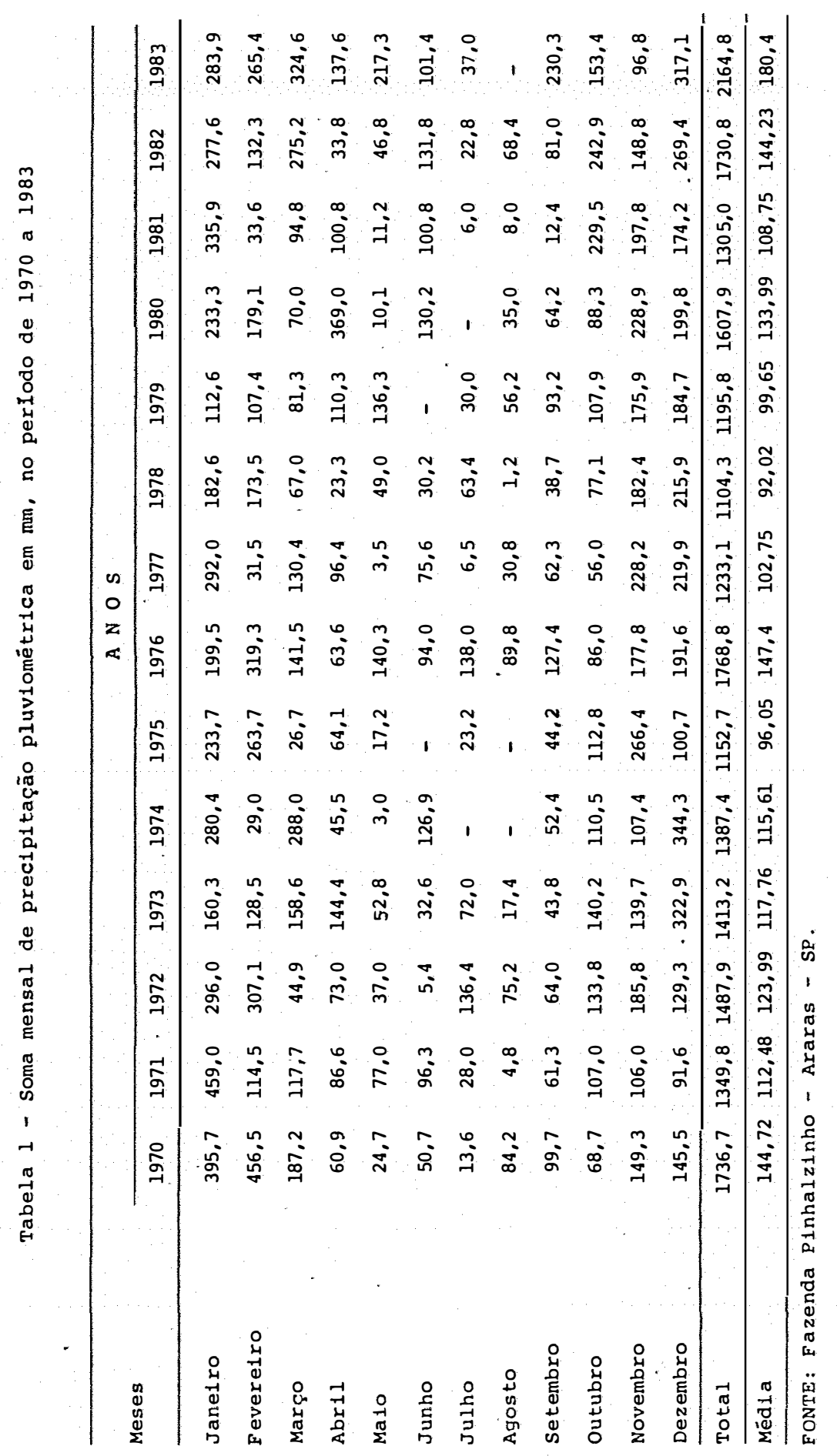




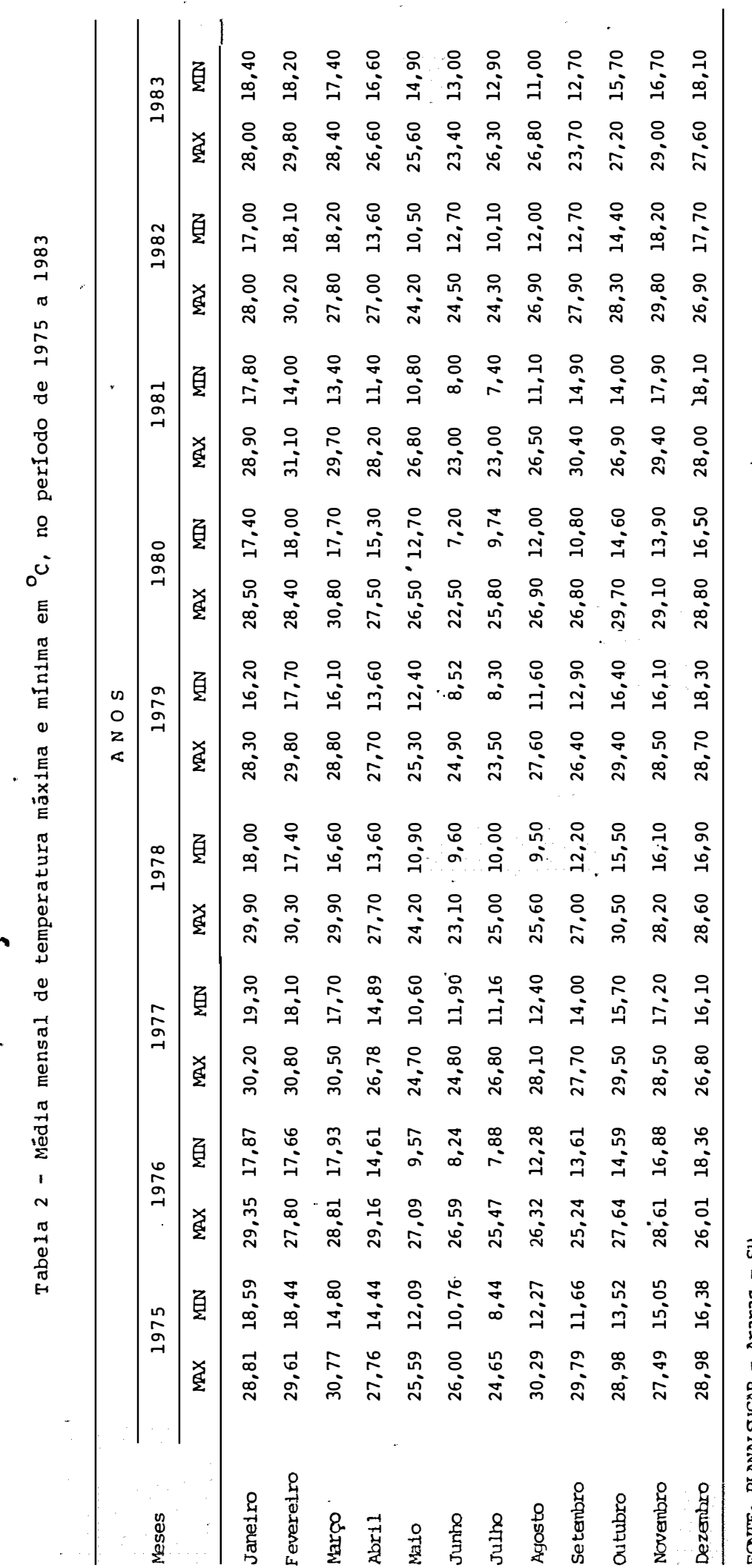



○

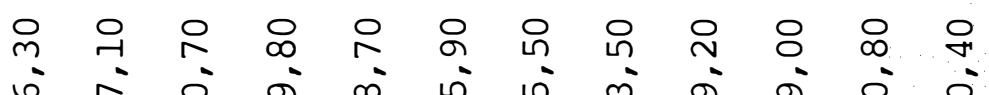

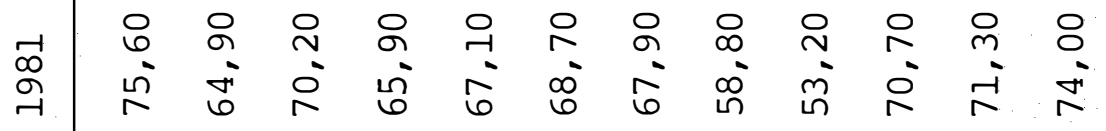

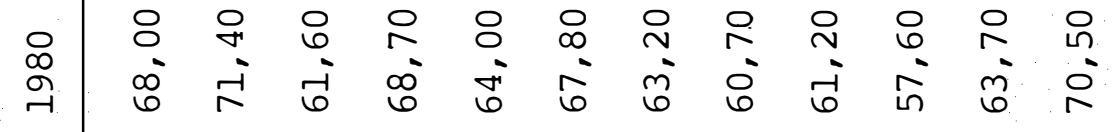

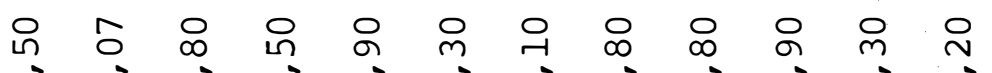
बi $\hat{6}$ के

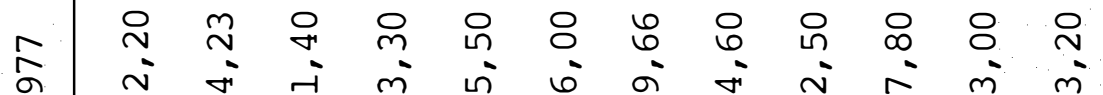

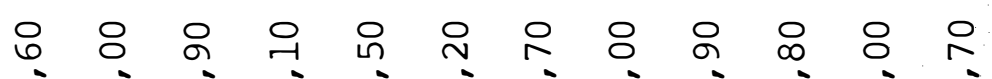

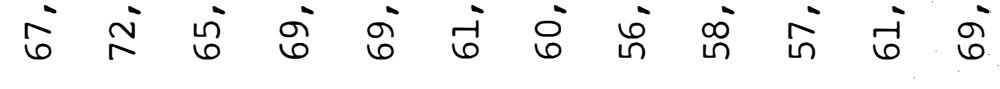

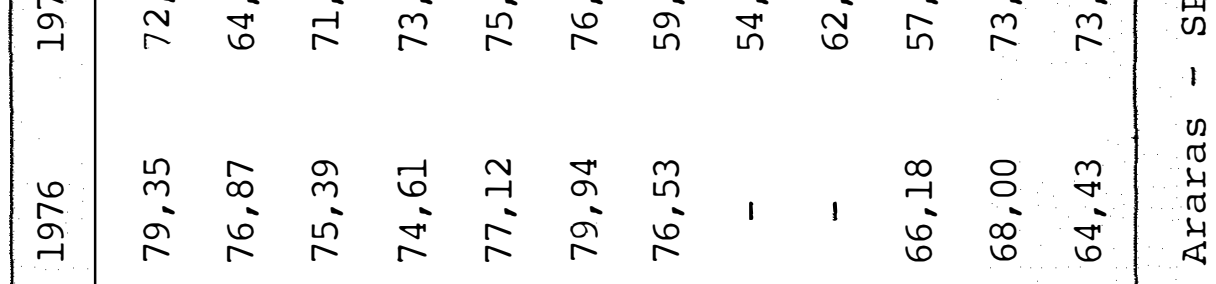
$\ddot{0}$ 吕

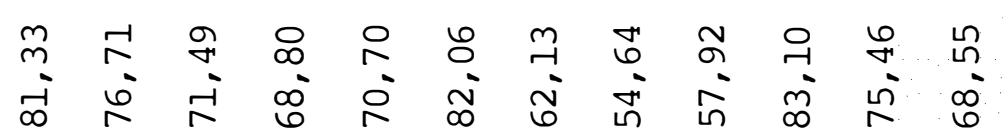

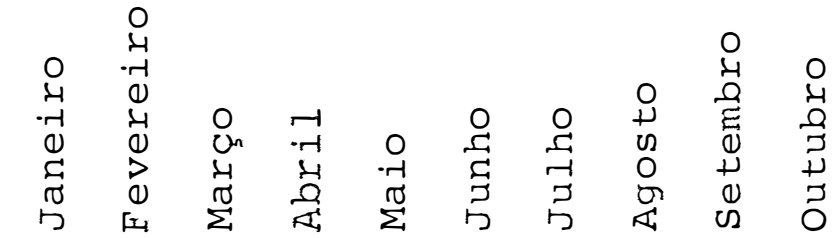

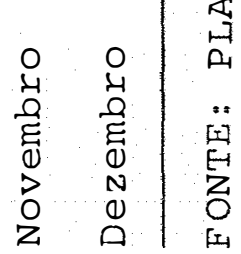


Tabela 4 - Análise de variāncia da produção de leite

\begin{tabular}{|c|c|c|c|c|}
\hline $\begin{array}{l}\text { Causa da } \\
\text { variação }\end{array}$ & G.L. & $\begin{array}{l}\text { Quadrados } \\
\text { Médios }\end{array}$ & (I) & (2) \\
\hline Ano de parição & 13 & $12832772,02 * \star$ & 7,60 & \\
\hline Linear & 1 & $56593808,09 * \star$ & & 33,92 \\
\hline Quadrātico & 1 & $271042,56 \mathrm{~ns}$ & & 0,16 \\
\hline Cúbico & 1 & $61475008,09 * \star$ & & 36,84 \\
\hline Quártico & 1 & $862112,50 \mathrm{~ns}$ & & 0,51 \\
\hline Quintico & 1 & $7318706,01 *$ & & 4,38 \\
\hline Desvios & 8 & $5038171,01 * \star$ & & 24,16 \\
\hline Epoca de parição & 3 & $2918003,50 \mathrm{~ns}$ & 0,39 & \\
\hline Grupo genētico & 4 & $24775136,05 * *$ & 4,51 & \\
\hline Linear & 1 & $66102616,09 * *$ & & 66,70 \\
\hline Quadrātico & 1 & $74528,59 \mathrm{~ns}$ & & 0,07 \\
\hline Cúbico & 1 & $27715488,05 * *$ & & 27,96 \\
\hline Quártico & 1 & 5207732,01 * & & 5,26 \\
\hline
\end{tabular}

Idade de vaca na Parição

$\begin{array}{llll}\text { Linear } & 1 & 18064124,04 * \star & 0,82 \\ \text { Quadrātico } & 1 & 91113920,18 * \star & 4,15\end{array}$

Resíduo

ns = não significativo ao nível de 5\% de probabilidade

* $=\mathrm{P}<0,05$

$\star \star=P<0,0.1$

$(1)=$ contrịbuição em : de soma de quadrado de cada efeito em relação à soma de quadrado total

$(2)=$ contribuição em o dos componentes linear,quadrático... em relação à somá dos quadrados decomposta. 
Tabela 5 - Análise da variância da duração da lactação conforme o modelo 1

\begin{tabular}{|c|c|c|c|c|}
\hline Causa da variação & G.L. & Quadrados Médios & (1) & (2) \\
\hline Ano de parição & 13 & $59442,60 * *$ & 6,63 & \\
\hline Linear & 1 & $362811,50 * *$ & & 46,95 \\
\hline Quadrātico & 1 & $130495,07 * \star$ & & 16,88 \\
\hline Cūbico & 1 & $9408,45 \mathrm{~ns}$ & & 1,21 \\
\hline Quártico & 1 & $30409,61 *$ & & 3,93 \\
\hline Quíntico & 1 & $22335,73 \mathrm{~ns}$ & & 2,89 \\
\hline Desvios & 8 & $27161,70 * *$ & & 28,12 \\
\hline Epoca de parição & 3 & $12401,13 \mathrm{~ns}$ & 0,31 & \\
\hline Grupo Genētico & 4 & $168050,91 * *$ & 5,76 & \\
\hline Linear & 1 & $455981,37 * \star$ & & 67,83 \\
\hline Quadrātico & 1 & $67600,18 * *$ & & 10,06 \\
\hline Cūbico & 1 & $147124,59 * *$ & & 21,89 \\
\hline Desvios & 1 & $1497,06 \mathrm{~ns}$ & & 0,22 \\
\hline
\end{tabular}

Idade da vaca no parto

Regressão linear $1 \quad 76157,59 * * \quad 0,66$

Residuo $\quad 1507 \quad 6699,07$

ns = não significativo ao nível de 5\% de probabilidade

* $=\mathrm{P}<0,05$

$\star \star=P<0,01$

$(1)=$ contribuição em ঃ da soma de quadrado de cada efeito em relação à soma de quadrado total

$(2)=$ contribuição em o dos componentes linear, quadrātico... em relação à soma de quadrado decomposta. 
Tabela 6. - Análise de variância da duração da lactação, incluindo ordem de parição

\begin{tabular}{|c|c|c|c|c|}
\hline Causa da variação & G.I. & Quadrado Médio & (1) & (2) \\
\hline Ano de parição & 13 & $57457,10 * *$ & 6,45 & \\
\hline Linear & 1 & $344446,87 * \star$ & & 46,11 \\
\hline Quadrātico & 1 & $122874,98 * *$ & & 16,45 \\
\hline cūbico & 1 & $14078,86 \mathrm{~ns}$ & & 1,88 \\
\hline Quártico & 1 & $28098,36 *$ & & 3,76 \\
\hline Quintico & 1 & $20419,50 \mathrm{~ns}$ & & 2,73 \\
\hline Desvios & 8 & $27127,99 * *$ & & 29.05 \\
\hline Época de parição & 3 & $12446,42 \mathrm{~ns}$ & 0,32 & \\
\hline Grupo genētico & 4 & $154677,65 * \star$ & 5,34 & \\
\hline Linear & 1 & $415870,19 * *$ & & 67,21 \\
\hline Quadrātico & 1 & $56531,35 * *$ & & 9,13 \\
\hline Cúbico & 1 & $143713,56 * *$ & & 23,22 \\
\hline Quártico & 1 & $2594,57 \mathrm{~ns}$ & & 0,41 \\
\hline Ordem de parição & 7 & $8935,74 \mathrm{~ns}$ & & - \\
\hline Linear & 1 & $51419,94 * \star$ & & 82,20 \\
\hline Quadrātico & 1 & $7732,30 \mathrm{~ns}$ & & 12,36 \\
\hline Cúbico & 1 & $1143,95 \mathrm{~ns}$ & & 1,83 \\
\hline Quārtico & 1 & $1465,44 \mathrm{~ns}$ & & 2,34 \\
\hline Quintico & 1 & $475,22 \mathrm{~ns}$ & & 0,75 \\
\hline Desvios & 2 & $156,69 \mathrm{~ns}$ & & 0,25 \\
\hline Resíduo & 1501 & 6734,92 & & \\
\hline
\end{tabular}

ns = não significativo ao nível de 5\% de probabilidade

* $=\mathrm{P}<0,05$

$\star \star=P<0,01$

$(1)=$ contribuição em ঃ da soma de quadrado de cada efeito em relação à soma de quadrado total

(2) = contribuição em o dos componentes linear, quadrático.... em relação à soma de quadrado decomposta 
Tabela 7 - Análise da variância da produção de leite ajustada por covariância para duração da lactação

\begin{tabular}{|c|c|c|}
\hline Causa de variação & G.L. & Quadrado \\
\hline Ano de parição & 13 & $22287188,05 * *$ \\
\hline Linear & 1 & $186515680,37 * *$ \\
\hline Quadrātico & 1 & $19090732,05 * *$ \\
\hline Cúbico & 1 & $43991384,09 * *$ \\
\hline Quārtico & 1 & $2303573,50 *$ \\
\hline Quintico & 1 & $1150823,75 \mathrm{~ns}$ \\
\hline Desvios & 8 & $4585169,01 * *$ \\
\hline Época de parição & 3 & 1491373,25 * \\
\hline Grupo genético & 4 & $2857194,00 * *$ \\
\hline Linear & 1 & $57094,94 \mathrm{~ns}$ \\
\hline Quadrātico & 1 & $7812330,01 * *$ \\
\hline Cúbico & 1 & $798111,87 \mathrm{~ns}$ \\
\hline Quārtico & 1 & $2761214,00 *$ \\
\hline
\end{tabular}

Idade da vaca na parição

$\begin{array}{llr}\text { Linear } & 1 & 2745151,50 * * \\ \text { Quadrático } & 1 & 68313104,18 \text { * }\end{array}$

Duração da lactação

$\begin{array}{lrr}\text { Linear } & 1 & 1170285059,00 * * \\ \text { Quadrático } & 1 & 21562772,05 * \text { * } \\ & 1505 & 466434,56\end{array}$

ns = não significativo ao nível de 5\% de probabilidade

* $\quad=P<0,05$

$* *=\mathrm{P}<0,0 \mathrm{I}$ 
Tabela ó - Média de produção de leite ajustada para duração de lactação e número de observações segundo o ano de parição

\begin{tabular}{lcc}
\hline Ano & $\begin{array}{c}\text { Número de } \\
\text { observações }\end{array}$ & $\begin{array}{c}\text { Produção de leite } \\
\pm \text { erro da média }\end{array}$ \\
\hline 1970 & 53 & $2239,65 \pm 98,78$ \\
1971 & 37 & $2426,77 \pm 114,16$ \\
1972 & 55 & $1980,26 \pm 94,20$ \\
1973 & 71 & $1778,42 \pm 82,53$ \\
1974 & 98 & $2569,72 \pm 70,05$ \\
1975 & 89 & $2818,33 \pm 73,76$ \\
1976 & 112 & $2990,27 \pm 65,59$ \\
1977 & 139 & $2900,41 \pm 59,50$ \\
1978 & 124 & $3268,29 \pm 62,94$ \\
1979 & 152 & $3586,74 \pm 56,82$ \\
1980 & 175 & $3342,56 \pm 53,46$ \\
1981 & 185 & $3438,59 \pm 52,39$ \\
1982 & 184 & $3326,04 \pm 53,11$ \\
1983 & 56 & $2991,83 \pm 97,51$ \\
\hline
\end{tabular}


Tabela 9 - Média de produção de leite ajustada para duração da lactação, por covariância e o número de observações, segundo a época de parição

\begin{tabular}{lcc}
\hline Época de parição & $\begin{array}{c}\text { Número de } \\
\text { observações }\end{array}$ & $\begin{array}{c}\text { Produção de leite } \\
\pm \text { erro da média }\end{array}$ \\
\hline Janeiro-Março & 353 & $2741,24 \pm 38,61$ \\
Abril-Junho & 393 & $2827,08 \pm 36,77$ \\
Julho-Setembro & 421 & $2890,56 \pm 36,60$ \\
Outubro-Dezembro & 363 & $2871,94 \pm 37,84$ \\
\hline
\end{tabular}

Tabela 10 - Média de produção de leite, ajustada para a duração da lactação por covariância e nümero de observações segundo o grupo genético

\begin{tabular}{lcc}
\hline Grupo genético & $\begin{array}{c}\text { Número de } \\
\text { observações }\end{array}$ & $\begin{array}{c}\text { Produção de leite } \\
\pm \text { erro da média }\end{array}$ \\
\hline
\end{tabular}

$1 / 2 \mathrm{H}: 1 / 2 \mathrm{GU}$

$3 / 4 \mathrm{H}: 1 / 4 \mathrm{GU}$

$7 / 8 \mathrm{H}: 1 / 8 \mathrm{GU}$

$15 / 16 \mathrm{H}: 1 / 16 \mathrm{GU}$

$31 / 32 \mathrm{H}: 1 / 32 \mathrm{GU}$

$\mathrm{H}=$ Holandès

$\mathrm{G}=$ Guzerā
156

356

455

281

282
$2906,84 \pm 58,66$

$2786,43 \pm 37,75$

$2688,52 \pm 34,74$

$2791,83 \pm 44,78$

$2899,90 \pm 46,16$ 
Tabela 11 - Produção de leite estimada em função da duração da lactação e fatores de correção multiplicativos para 305 dias de lactação

\begin{tabular}{|c|c|c|}
\hline \multirow{2}{*}{$\begin{array}{l}\text { Duração da } \\
\text { lactação } \\
\text { (dias) }\end{array}$} & \multirow{2}{*}{$\begin{array}{c}\text { Produção de leite } \\
\text { estimada } \\
(\mathrm{kg})\end{array}$} & Correção para \\
\hline & & 305 dias \\
\hline 120 & 1169,62 & 2,8583 \\
\hline 135 & 1365,22 & 2,4488 \\
\hline 150 & 1557,40 & 2,1466 \\
\hline 165 & 1746,16 & 1,9145 \\
\hline 180 & 1931,51 & 1,7308 \\
\hline 195 & 2113,44 & 1,5818 \\
\hline 210 & 2291,95 & 1,4608 \\
\hline 225 & 2467,04 & 1,3572 \\
\hline 240 & 2638,72 & 1,2688 \\
\hline 255 & 2806,98 & 1.1928 \\
\hline 270 & 2971,83 & 1,1267 \\
\hline 285 & 3133,26 & 1,0686 \\
\hline 300 & 3291,27 & 1,0172 \\
\hline 305 & 3343,18 & 1,0000 \\
\hline 3.15 & 3445,86 & 0,9716 \\
\hline 330 & 3597,04 & 0,9308 \\
\hline 345 & 3744,79 & 0,8941 \\
\hline 360 & 3889,14 & 0,8609 \\
\hline 375 & 4030,07 & 0,8308 \\
\hline
\end{tabular}


Tabela 12 - Análise da variância da produção de leite de acordo com o modelo 3

\begin{tabular}{|c|c|c|}
\hline Causa de variação & G.L. & Quadrados Médios \\
\hline Ano de parição & 13 & 7799623,01 \\
\hline Linear & 1 & 12483034,02 \\
\hline Quadrātico & 1 & 940527,37 \\
\hline Cūbico & 1 & 52709808,09 \\
\hline Quārtico & 1 & 69809,28 \\
\hline Quíntico & 1 & 1636772,25 \\
\hline Desvios & 8 & 4194397,01 \\
\hline Época de parição & 3 & 1364804,75 \\
\hline Grupo genētico & 4 & 5574133,01 \\
\hline Linear & 1 & 10250846,02 \\
\hline Quadrātico & 1 & 8518372,02 \\
\hline Cūbico & 1 & 826326,00 \\
\hline Quārtico & 1 & 2700930,00 \\
\hline Touro & 23 & $3804900,50 * *$ \\
\hline \multicolumn{3}{|l|}{$\begin{array}{l}\text { Idade da vaca na } \\
\text { parição }\end{array}$} \\
\hline Linear & 1 & 73935344,18 \\
\hline Quadrātico & 1 & 72705072,21 \\
\hline Resíduo & 1328 & 1185151,00 \\
\hline
\end{tabular}

** Significativo ao nível de $1 \%$ de probabilidade. Obs: O valor do coeficiente $K$ para $O$ componente de variância entre touros foi igual a 45,59. 
Tabela 13 - Análise da variância da duração da lactação de acordo com o modelo 3

\begin{tabular}{|c|c|c|}
\hline Causa de variação & G.L. & Quadrado Médio \\
\hline Ano de parição & 13 & 29092,61 \\
\hline Linear & 1 & 106651,25 \\
\hline Quadrático & 1 & 44365,22 \\
\hline Cūbico & 1 & 31423,55 \\
\hline Quártico & 1 & 9438,37 \\
\hline Quíntico & $i$ & 5724,16 \\
\hline Desvios & 8 & 22575,19 \\
\hline Epoca de parição & 3 & 9147,98 \\
\hline Grupo genético & 4 & 24494,46 \\
\hline Linear & 1 & 86456,07 \\
\hline Quadrātico & 1 & 2251,12 \\
\hline Cúbico & 1 & 9116,37 \\
\hline Quártico & 1 & 154,07 \\
\hline Touro & 23 & $20965,42^{* *}$ \\
\hline \multicolumn{3}{|l|}{$\begin{array}{l}\text { Idade da vaca na } \\
\text { parição }\end{array}$} \\
\hline Linear & 1 & 49561,60 \\
\hline Quadrātico & 1 & 26658,59 \\
\hline Resíduo & 1328 & 6690,99 \\
\hline
\end{tabular}

** Significativo a lo de probabilidade.

Obs: O valor do coeficiente $K$ para o componente de variância entre touros foi igual a 45,59. 
Tabela 14 - Análise da variância da produção de leite ajustada para duração da lactação de acordo com o modelo 3

\begin{tabular}{|c|c|c|}
\hline Causa de variação & G.L. & Quadrados Médios \\
\hline Ano de parição & 13 & 8358761,01 \\
\hline Linear & 1 & 47178728,10 \\
\hline Quadrātico & 1 & 3141558,00 \\
\hline Cúbico & 1 & 25548796,05 \\
\hline Quártico & 1 & 1234019,75 \\
\hline Quíntico & 1 & 370527,81 \\
\hline Desvios . & 8 & 3898788,50 \\
\hline Epoca de parição & 3 & $693856 ; 75$ \\
\hline Grupo genético & 4 & 1799240,75 \\
\hline Linear & 1 & $. .44685,85$ \\
\hline Quadrātico & 1 & 5038923,01 \\
\hline Cúbico & 1 & 16462,41 \\
\hline Quártico & 1 & 2096890,00 \\
\hline Touro & 23 & $850734,87 \star \star$ \\
\hline \multicolumn{3}{|l|}{$\begin{array}{l}\text { Idade da vaca na } \\
\text { parição }\end{array}$} \\
\hline Linear & 1 & 36250088,09 \\
\hline Quadrātico & 1 & 43043672,10 \\
\hline \multicolumn{3}{|c|}{ Duração da lactação } \\
\hline Linear & 1 & 999579265,50 \\
\hline Quadrático & 1 & 20502988,05 \\
\hline Resíduo & 1326 & 428525,87 \\
\hline
\end{tabular}

* * Significativo a $1 \%$ de probabilidade

Obs: O valor do coeficiente $K$ para o componente de variância entre touros foi igual a 45,46 . 